Research paper

\title{
Discovery of phenylsulfonylfuroxan derivatives as gamma globin inducers by histone acetylation
}

\author{
Thais Regina Ferreira de Melo ${ }^{a}$, Chutima Kumkhaek ${ }^{b}$, \\ Guilherme Felipe dos Santos Fernandes a, Maria Elisa Lopes Pires c, \\ Rafael Consolin Chelucci ${ }^{a}$, Karina Pereira Barbieri ${ }^{a}$, Fernanda Coelho ${ }^{\mathrm{d}}$, \\ Ticiana Sidorenko de Oliveira Capote ${ }^{\mathrm{d}}$, Carolina Lanaro ${ }^{\mathrm{c}}$, Iracilda Zeppone Carlos ${ }^{\mathrm{a}}$, \\ Sisi Marcondes ${ }^{\text {C }}$, Konstantin Chegaev ${ }^{\mathrm{e}}$, Stefano Guglielmo ${ }^{\mathrm{e}}$, Roberta Fruttero ${ }^{\mathrm{e}}$, \\ Man Chin Chung a , Fernando Ferreira Costa ${ }^{c}$, Griffin P. Rodgers ${ }^{b}$, \\ Jean Leandro dos Santos ${ }^{\text {a, * }}$ \\ a São Paulo State University (UNESP), School of Pharmaceutical Sciences, Araraquara, 14800-903, Brazil \\ b Molecular and Clinical Hematology Branch, National Heart, Lung, and Blood Institute, Bethesda, MD 20892, United States \\ ${ }^{c}$ Faculty of Medical Sciences, State University of Campinas - UNICAMP, Campinas, 13083-970, Brazil \\ d São Paulo State University (UNESP), School of Dentistry, Araraquara, 14801-903, Brazil \\ e Dipartimento di Scienza e Tecnologia del Farmaco, Università degli Studi di Torino, Turin, 10124, Italy
}

\section{A R T I C L E I N F O}

\section{Article history:}

Received 29 March 2018

Received in revised form 5 May 2018

Accepted 7 May 2018

Available online 30 May 2018

\section{Keywords:}

Analgesic activity

Antiplatelet activity

Epigenetic

Fetal hemoglobin

Furoxan

Sickle cell disease

\begin{abstract}
A B S T R A C T
$\mathrm{N}$-oxide derivatives $\mathbf{5}(\mathbf{a}-\mathbf{b}), \mathbf{8}(\mathbf{a}-\mathbf{b})$, and $\mathbf{1 1}(\mathbf{a}-\mathbf{c})$ were designed, synthesized and evaluated in vitro and in vivo as potential drugs that are able to ameliorate sickle cell disease (SCD) symptoms. All of the compounds demonstrated the capacity to releasing nitric oxide at different levels ranging from 0.8 to $30.1 \%$, in vivo analgesic activity and ability to reduce TNF- $\alpha$ levels in the supernatants of monocyte cultures. The most active compound (8b) protected $50.1 \%$ against acetic acid-induced abdominal constrictions, while dipyrone, which was used as a control only protected $35 \%$. Compounds $\mathbf{8 a}$ and $\mathbf{8 b}$ inhibited ADP-induced platelet aggregation by $84 \%$ and $76.1 \%$, respectively. Both compounds increased $\gamma$ globin in K562 cells at $100 \mu \mathrm{M}$. The mechanisms involved in the $\gamma$-globin increase are related to the acetylation of histones $\mathrm{H} 3$ and $\mathrm{H} 4$ that is induced by these compounds. In vitro, the most promising compound $(\mathbf{8 b})$ was not cytotoxic, mutagenic and genotoxic.
\end{abstract}

(C) 2018 Elsevier Masson SAS. All rights reserved.

\section{Introduction}

Sickle Cell Disease (SCD) is one of the most prevalent genetic hemoglobinopathies worldwide. The disease is caused by a single nucleotide polymorphism (GTC to GAC) at the sixth codon of the $\beta$ globin gene, which causes the substitution of glutamic acid (Glu6) to valine (Val6) [1]. Under low oxygen stress, the interactions of hydrophobic $\beta$-chains promote the polymerization of sickle hemoglobin (HbS) inside red blood cells (RBCs) and cause changes in the erythrocyte cytoskeleton that result in rigid and irregularly shaped cells that are prone to hemolysis [2]. Erythrocyte damage

\footnotetext{
* Corresponding author.

E-mail address: santosjl@fcfar.unesp.br (J.L. dos Santos).
}

leads to the release of cell-free hemoglobin and arginase. The heme group sequesters nitric oxide (NO) from the vascular endothelium and causes the 'vasoconstriction crisis' that is commonly found in sickle cell patients [3]. Furthermore, NO deficiency contributes to vasculopathy and hypercoagulability $[4,5]$.

Abnormal adhesion of red blood cells to the vascular endothelium and their increased interaction with leucocytes and platelets leads to the formation of heterocellular aggregates, which are responsible for the vaso-occlusion phenomenon that leads to the main clinical symptoms of SCD, including ischemia, acute chest syndrome, priapism, pain crisis and strokes [6,7].

Hydroxyurea ( $\mathrm{HU}$ ) and glutamine are the only therapeutic alternatives approved by the Food and Drug Administration (FDA) to treat sickle cell disease $[8,9]$. HU acts as a selective inhibitor of 


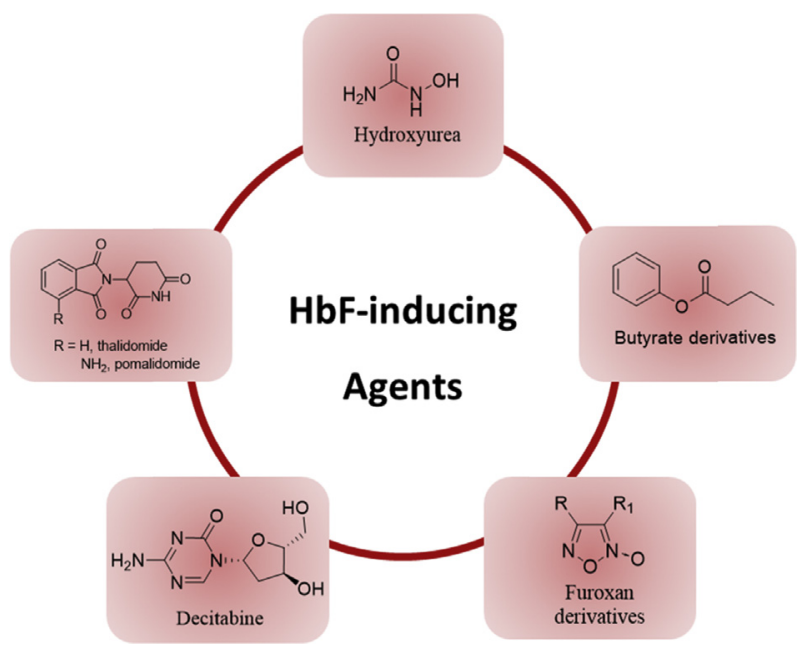

Fig. 1. Structures of current state-of-the-art of HbF-inducing agents in SCD treatment.

ribonucleotide diphosphate reductase synthesis, an enzyme required to convert diphosphate ribonucleotides to diphosphate deoxyribonucleotides. This drug prevents the cells leaving the G1/S phase of the cell cycle, being used mainly in neoplasias of the hematopoietic system [8]. For SCD patients, HU demonstrates multiple beneficial effects, including an increase of fetal hemoglobin levels and reduction of cellular adhesion to the vessel endothelium [9]; however, serious adverse effects, such as myelosuppression, limit its long-term use. In addition, approximately one-third of adult patients do not respond to HU therapy, justifying the search for new drugs [6,10].

The current 'state-of-art' for discovery new drugs to treat SCD include several approaches such as: a) inhibition of erythrocyte dehydratation (eg. senicapoc); b) cellular adhesion inhibitors (e.g., rivipansel); c) adenosine agonists (e.g., regadenoson); d) Rhokinase (Rock) inhibitors (e.g., hydroxy-fasudil); e) chelating agents (e.g., deferasirox) and f) fetal hemoglobin (HbF) inducers (Fig. 1). Among these strategies, that aiming to increase $\mathrm{HbF}$ is the most promising [11] and several agents that act through this mechanism have been described. Reactivation of $\mathrm{HbF}$ in adults ameliorates the clinical symptoms of sickle cell disease [12]. Currently, experimental HbF inducers include a) nucleoside analogues with inhibitory effects on DNA methyltransferases (e.g., decitabine), b) histone deacetylase inhibitors (e.g., butyric acid), c) thalidomide and pomalidomide and; d) NO-donors (e.g., furoxan) among others [12,13].

Several molecular mechanisms are involved in $\gamma$-globin gene silencing in adult erythroid cells [14]. These mechanisms include epigenetic DNA modifications, such as histone modifications and DNA methylation [15]. Studies have shown that thalidomide induces $\gamma$-globin expression through the p38 MAPK phosphorylation pathway as well as histone $\mathrm{H} 4$ acetylation [16,17]. Its analogue pomalidomide induces $\mathrm{HbF}$ synthesis and modulates erythrocyte differentiation by decreasing the levels of the transcriptional factors BCL11-A and SOX-6 during erythropoiesis [18,19].

Other $\mathrm{HbF}$ inducer compounds include NO-donors. $\mathrm{N}$-oxide compounds (e.g., furoxan) are widely known for their ability to release NO [20-23]. Experimental data revealed that NO-released from furoxan occurs due to the nucleophilic attack of thiol groups present in L-cysteine residues into furoxan nucleus leading to the formation of intermediate that undergo ring oppening to a nitroso derivative. Further, NO is formed by oxidation of eliminated nitrosyl anions [24,25]. NO contributes to increase fetal hemoglobin levels through activation of the soluble guanylyl cyclase (sGC) pathway [26]. Therefore, the synergistic combination of thalidomide within $\mathrm{N}$-oxide subunits is a useful strategy to increase HbF [10].<smiles>O=C1CCC(N2C(=O)c3ccccc3C2=O)C(I)C1</smiles>

Thalidomide

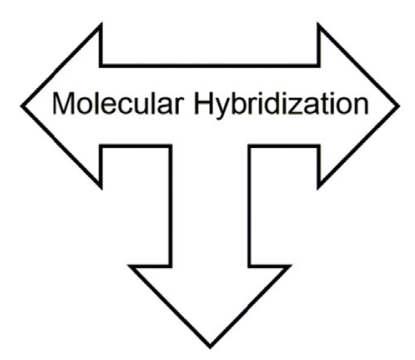

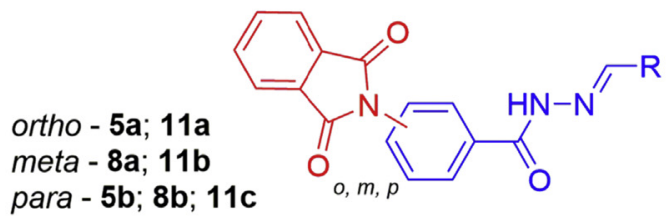
para - 5b; 8b; 11c

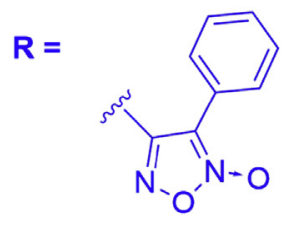

ortho - 5 a para $-\mathbf{5 b}$

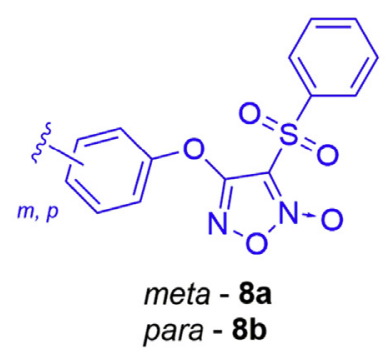<smiles>CC(=O)Oc1ccccc1C(=O)Oc1ccc(C(=O)N/N=C/c2no[n+]([O-])c2CI)cc1</smiles>

$(E)-3-((2-(4-((2-$ acetoxybenzoyl)oxy)benzoyl)hydrazono)m ethyl)-4-phenyl-1,2,5-oxadiazole 2- $\mathrm{N}$-oxide

Rosseto et al., 2015

Fig. 2. Design of the hybrid furoxan derivatives. 

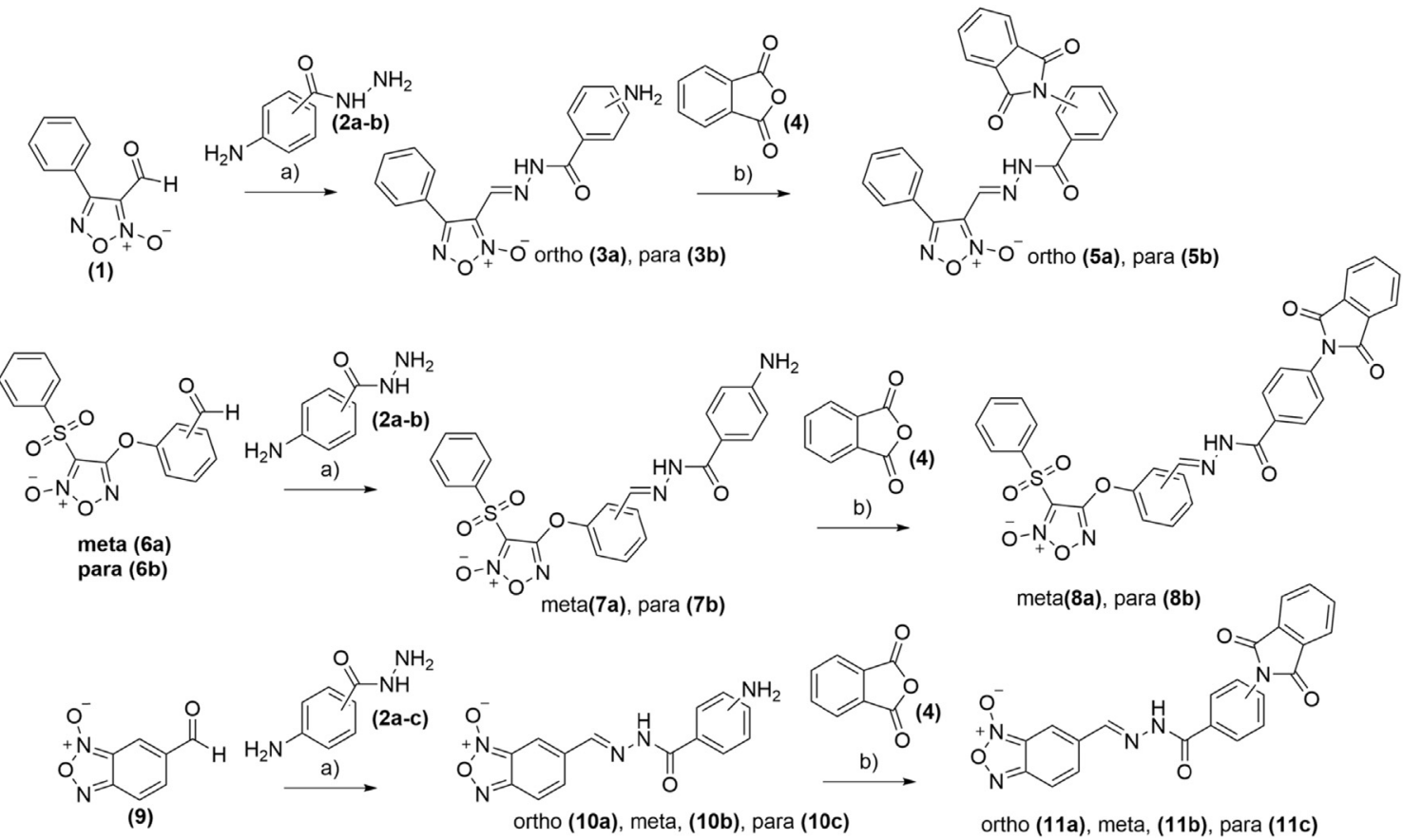

Scheme. 1. Synthesis of $N$-oxide-thalidomide analogues.

a Reagents and conditions: a) aminobenzhydrazides, EtOH, $\mathrm{H}^{+}$, r. t. 4-24 h; b) phthalic anhydride, EDC, DMAP, DMF anhydrous, $\mathrm{N}_{2}$ atmosphere, r. t., 24-30 h.

During the drug design both furoxan and phthalimide subunits were linked using as spacer the $\mathrm{N}$-acil-hydrazone subunit. This spacer was described as presenting antiplatelet and antithrombotic activity [27]. Specifically, the compound (E)-3-((2-)(4-((2acetoxybenzoyl)oxy)benzoyl)hydrazono)methyl)-4-phenyl-1,2,5oxadiazole 2-N-oxide (Fig. 2), used as prototype, was able to inhibit ADP-induced platelet aggregation up to 68.8\% [27]. Here, we report the synthesis and pharmacological study of $\mathrm{N}$-oxide derivatives aimed at inducing HbF. Analgesic, anti-inflammatory and antiplatelet effects that are useful for preventing vaso-occlusion were also studied. The putative mechanism of action for the most active compounds was characterized to provide a new alternative to HU that will be useful for ameliorating sickle cell disease symptoms.

\section{Results}

\subsection{Chemistry}

The synthetic routes for the preparation of the $\mathrm{N}$-oxide
Table 2

In vivo antinociceptive effects of dipyrone (Dyp) and compounds $\mathbf{5}(\mathbf{a}-\mathbf{b})$, $\mathbf{8}(\mathbf{a}-\mathbf{b})$, and 11(a-c) using acetic acid-induced mice abdominal constrictions. The data are expressed as the percentage of inhibition of the total writhings induced by acetic acid $(\mathrm{n}=8)$.

\begin{tabular}{ll}
\hline Compound & \% protection $(100 \mu \mathrm{mol} / \mathrm{kg}$, p.o. $)$ \\
\hline Dip & $35.0 \pm 1.5$ \\
5a & $36.2 \pm 2.2$ \\
$\mathbf{5 b}$ & $44.8 \pm 1.8^{*}$ \\
8a & $42.0 \pm 1.2^{*}$ \\
8b & $50.1 \pm 1.6^{*}$ \\
11a & $30.5 \pm 2.5$ \\
11b & $40.5 \pm 2.5^{*}$ \\
11c & $48.3 \pm 3.1^{*}$ \\
\hline
\end{tabular}

*, p $<0.01$ compared to dipyrone (ANOVA followed by Dunnett's test).

derivatives $\mathbf{5}(\mathbf{a}-\mathbf{b}), \mathbf{8}(\mathbf{a}-\mathbf{b})$, and $\mathbf{1 1}(\mathbf{a}-\mathbf{c})$ are outlined in Scheme 1 . The derivatives were obtained in two steps with overall yields ranging from 25 to 55\%. The first step of the synthesis involved the

Table 1

NO-release and inhibition of platelet aggregation induced by ADP $(10 \mu \mathrm{M})$ in platelet-rich plasma.

\begin{tabular}{|c|c|c|}
\hline Compounds & $\% \mathrm{NO}_{2}^{-}(\mathrm{mol} / \mathrm{mol}) 50 \times 10^{-4} \mathrm{M}$ of L-Cys ${ }^{\mathrm{a}}$ & ADP-induced platelet aggregation (\% inhibition) ${ }^{\mathrm{b}}$ \\
\hline ASA & - & $5.0 \pm 1.1$ \\
\hline DNS & $12.2 \pm 0.9$ & - \\
\hline $5 a$ & $16.4 \pm 0.8$ & $17.2 \pm 2.8^{t^{*}}$ \\
\hline $5 \mathbf{b}$ & $17.1 \pm 0.2$ & $26.5 \pm 0.8^{t^{*}}$ \\
\hline $8 a$ & $30.1 \pm 0.5$ & $84.0 \pm 1.3^{t^{*}}$ \\
\hline $8 b$ & $23.7 \pm 0.9$ & $76.1 \pm 1.6^{\dagger *}$ \\
\hline 11a & 0 & 0 \\
\hline 11b & 0 & $1.2 \pm 0.5$ \\
\hline 11c & 0 & $2.8 \pm 1.1$ \\
\hline
\end{tabular}

${ }^{*} p<0.01 v s$. the control group.

${ }^{t} p<0.01 v$ v. ASA. ASA, acetylsalicylic acid; ADP, adenosine diphosphate; DNS, isosorbide dinitrate.

a NO-release measured after incubation of the listed compounds with a 1:50 M excess of L-cysteine.

b Effects of DNS $(100 \mu \mathrm{M})$ and the $N$-oxide derivatives $\mathbf{5}(\mathbf{a}-\mathbf{b}), \mathbf{8}(\mathbf{a}-\mathbf{b})$, and $\mathbf{1 1}(\mathbf{a}-\mathbf{c}) 100 \mu \mathrm{M}$ and acetylsalicylic acid (ASA) (100 $\mu \mathrm{g} / \mathrm{kg})$ on platelet inhibition induced by ADP $(10 \mu \mathrm{M})$ in platelet-rich plasma. The data are expressed as the means \pm standard errors of the means. Significant differences between the experimental and control groups were evaluated by analysis of variance followed by the Tukey test. 
Table 3

Level of pro-inflammatory mediator TNF- $\alpha$ determined by ELISA in the supernatant of macrophage mononuclear culture treated with LPS and co-incubated with the test compounds $\mathbf{5 b}, \mathbf{8}(\mathbf{a}-\mathbf{b})$ and $\mathbf{1 1}(\mathbf{b}-\mathbf{c})$.

\begin{tabular}{lllll}
\hline Compound & \multicolumn{5}{l}{ \% TNF- $\alpha$ inhibition } \\
\cline { 2 - 5 } & $6.2 \mu \mathrm{M}$ & $12.5 \mu \mathrm{M}$ & $25 \mu \mathrm{M}$ & $50 \mu \mathrm{M}$ \\
\hline Control (-) & - & - & - & - \\
Thal & - & - & - & 31.7 \\
$\mathbf{5 b}$ & - & - & - & - \\
$\mathbf{8 a}$ & $61.0^{*}$ & $64.9^{*}$ & $73.6^{*}$ & - \\
$\mathbf{8 b}$ & $41.0^{*}$ & $54.2^{*}$ & $76.5^{*}$ & - \\
$\mathbf{1 1 b}$ & - & - & - & - \\
$\mathbf{1 1 c}$ & $\mathrm{ND}$ & $99.9^{*}$ & $99.5^{*}$ & $54.5^{*}$ \\
\hline
\end{tabular}

Thalidomide (Thal) $(50 \mu \mathrm{M})$ was used as the reference drug. *, $\mathrm{p}<0.05$ (ANOVA followed by Tukey's Multiple Comparison Test). All of the tested-compounds demonstrated levels of significance compared with the control (-). The asterisk $\left({ }^{*}\right)$ denotes the level of significance of the difference between Thal and the tested compounds $(\mathrm{n}=3)$. coupling reaction of furoxan derivatives $(\mathbf{1}, \mathbf{6}(\mathbf{a}-\mathbf{b})$ and $\mathbf{9})$ with hydrazides $\mathbf{2}(\mathbf{a}-\mathbf{c})$ in a solution containing ethanol and acetic acid with variable yields ranging from 34 to $75 \%$. In the last step, phthalic anhydride and amino derivatives were condensed using 1ethyl-3-(3-dimethylaminopropyl)carbodiimide (EDC) and 4dimethylaminopyridine (DMAP) as coupling reagents to obtain the proposed $\mathrm{N}$-oxide derivatives with global yields ranging from 17 to $55 \%$. All of the compounds were analyzed by HPLC, and their purities were confirmed to be over $98.5 \%$. The ${ }^{1} \mathrm{HNMR}$ spectra of all of the intermediates showed one signal that corresponded to the ylidenic hydrogen of the E-diastereomers [28,29].

\subsection{Detection of nitrite (Griess reaction)}

The nitrite produced by all of the $N$-oxide derivatives at $100 \mu \mathrm{M}$, $\mathbf{5}(\mathbf{a}-\mathbf{b}), \mathbf{8}(\mathbf{a}-\mathbf{b})$, and $\mathbf{1 1}(\mathbf{a}-\mathbf{c})$, resulted from the oxidation of NO with oxygen and water [30-32]. The quantity of NO produced was
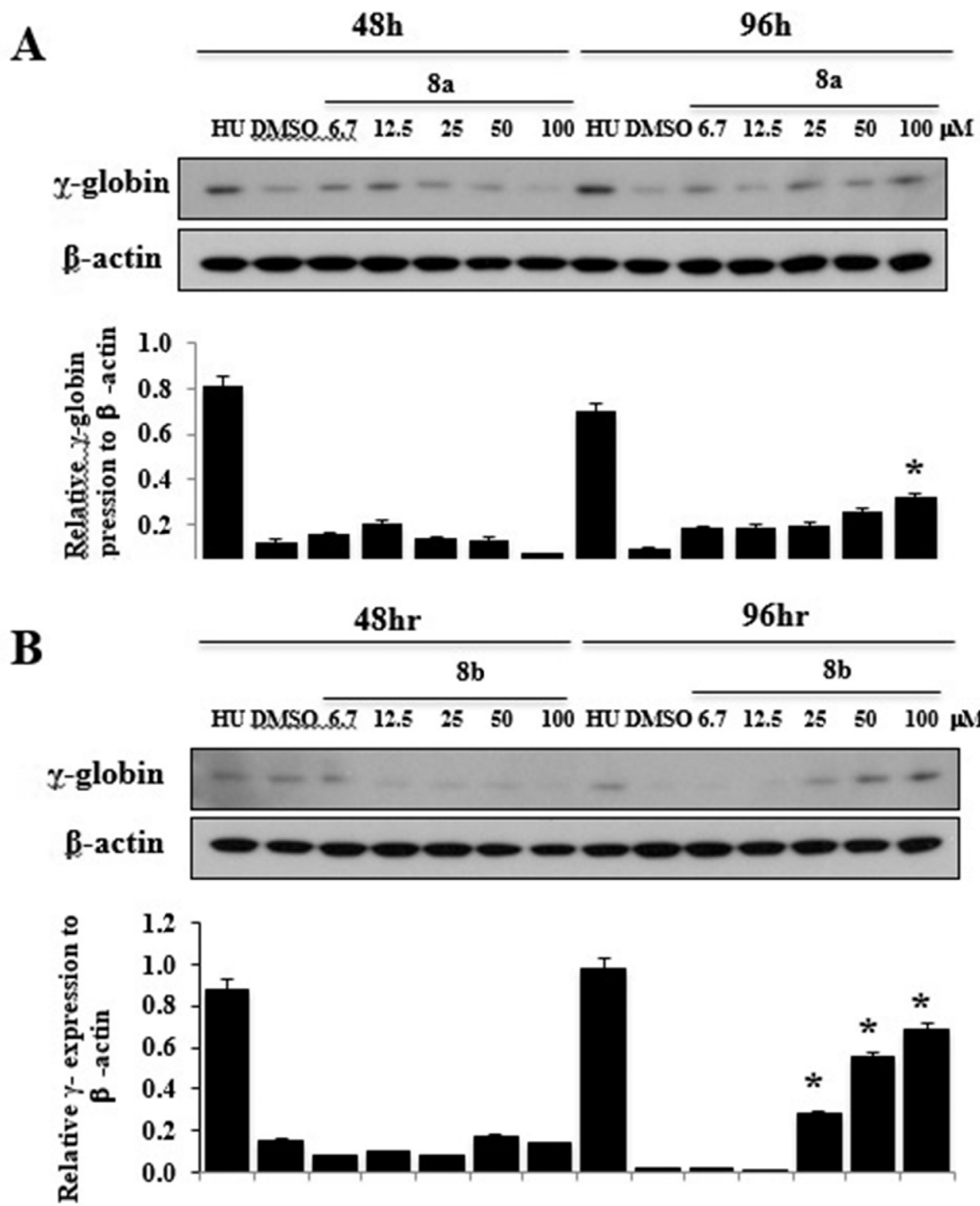

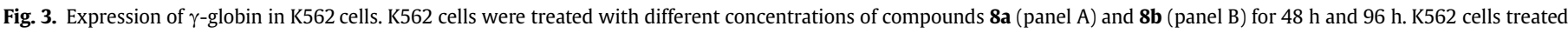

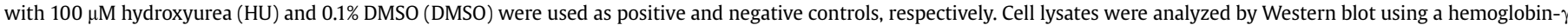

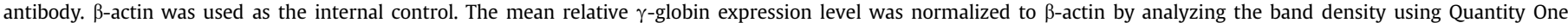
software. The error bars represent the SD from 3 individual experiments, ${ }^{*} \mathrm{p}<0.05$. 
measured using the Griess reaction [20]. Thiol-induced NO generation was determined after incubating the compounds for $1 \mathrm{~h}$ in the presence of a large excess of L-cysteine (1:50). The results are expressed as a percentage of nitrite $\left(\mathrm{NO}_{2}^{-} ; \mathrm{mol} / \mathrm{mol}\right)$ and are summarized in Table 1.

Compounds $\mathbf{5}(\mathbf{a}-\mathbf{b}), \mathbf{8}(\mathbf{a}-\mathbf{b})$, and $\mathbf{1 1}(\mathbf{a}-\mathbf{c})$ were capable of inducing nitrite formation at levels ranging from 0.8 to $30.1 \%$ after $1 \mathrm{~h}$. Isosorbide dinitrate (DNS), which contains two organic nitrate esters that are capable of releasing NO, was used as the control. With DNS, we observed a $12.2 \%$ induction of nitrite formation. The relationship between the NO-release capacity and pattern of substitution at C-3 for the furoxan subunit was observed. Furoxan derivatives containing electron-withdrawing substituents at the 3position released more NO than those containing weak electronwithdrawing groups. It was found that phenyl-sulfonyl derivatives (8a-b) were the best NO-donors, followed by phenyl (5ab) derivatives. Benzofuroxan derivatives (11a-c) did not release NO under this experimental condition. In the absence of L-cysteine it was not observed production of nitrite in the medium.

Moreover, we have evaluated in vitro the chemical stability of compound $\mathbf{8 b}$ at pH 7.4 using a validated HPLC-UV method. The results showed a reduction of approximately $30 \%$ of concentration after $4 \mathrm{~h}$, and it suggest that compound $\mathbf{8 b}$ has a good stability in this $\mathrm{pH}$ (Supplementary Figure S1).

The capacity of all of the compounds to inhibit platelet aggregation induced by ADP $(10 \mu \mathrm{M})$ was evaluated using rat plateletrich plasma (Table 1) [33]. For this assay, all of the compounds, including the control acetylsalicylic acid (ASA), were tested at $100 \mu \mathrm{M}$. The results show that all of the compounds, except 11a, inhibited platelet aggregation at levels ranging from 1.2 to $84 \%$ (Table 1). Phenyl-sulfonyl derivatives $\mathbf{8}(\mathbf{a}-\mathbf{b})$ were the most active compounds and inhibited the aggregation induced by ADP by $84 \%$ and $76.1 \%$, respectively. Benzofuroxan derivatives $\mathbf{1 1}(\mathbf{b}-\mathbf{c})$ were weak inhibitors of the platelet aggregation induced by ADP. The prodrug clopidogrel did not inhibit platelet aggregation in this in vitro assay (data not shown).

\subsection{Antinociceptive activity}

The antinociceptive profiles of compounds $\mathbf{5}(\mathbf{a}-\mathbf{b}), \mathbf{8}(\mathbf{a}-\mathbf{b})$, and 11(a-c) were evaluated using acetic acid-induced abdominal constrictions in mice [34]. All of the compounds were administered orally at $100 \mu \mathrm{mol} / \mathrm{kg}$. Compounds $\mathbf{5 b}, \mathbf{8}(\mathbf{a}-\mathbf{b})$ and $\mathbf{1 1}(\mathbf{b}-\mathbf{c})$ exhibited antinociceptive effects superior to that of dipyrone, which was used as control, at the same dose (Table 2). Compound 8b was the most active antinociceptive molecule and reduced the number of induced abdominal constrictions by $50.1 \%$. Compound 11a showed antinociceptive activity inferior to that of dipyrone.

\subsection{Quantification of TNF- $\alpha$ levels in the macrophage supernatant}

The levels of proinflammatory cytokine TNF- $\alpha$ were determined by ELISA in the supernatant of a macrophage culture treated with LPS and co-incubated with the most active compounds identified in the analgesic assay, $\mathbf{5 b}, \mathbf{8}(\mathbf{a}-\mathbf{b})$, and $\mathbf{1 1}(\mathbf{a}-\mathbf{b})$. LPS $(50 \mathrm{mg} / \mathrm{mL})$ was used as an inflammatory stimulus (not shown). For this assay, a dose-response curve for characterizing cell viability was initially determined to identify the concentrations required for TNF- $\alpha$ quantification for each compound. Only those concentrations that led to cell viability greater than $75 \%$ were considered. Compounds $\mathbf{1 1}(\mathbf{b}-\mathbf{c})$ were added to cultured cells at concentrations of $12.5 \mu \mathrm{M}$, $25 \mu \mathrm{M}$ and $50 \mu \mathrm{M}$. For compounds $\mathbf{5 b}$ and $\mathbf{8}(\mathbf{a}-\mathbf{b})$, the concentrations were $6.2 \mu \mathrm{M}, 12.5 \mu \mathrm{M}$ and $25 \mu \mathrm{M}$. The control thalidomide at $50 \mu \mathrm{M}$ inhibited $31.7 \%$ of TNF- $\alpha$ production (Table 3 ). Compounds

A

\title{
$8 \mathbf{a}$

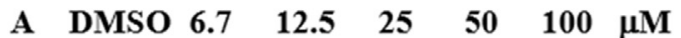

\section{phospho-p38 \\ total-p38}

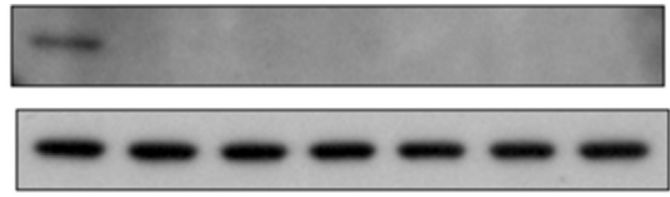

$\beta$-actin

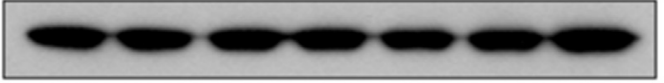

B

$8 b$

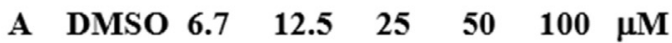

\author{
phospho-p38 \\ total-p38 \\ $\beta$-actin
}
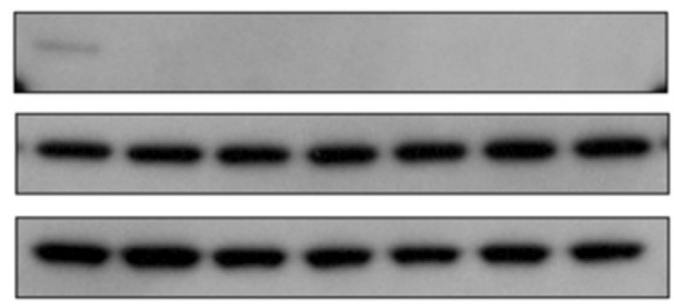

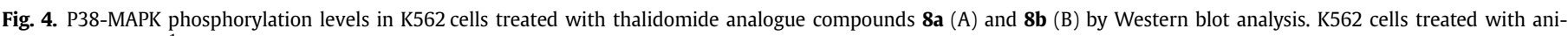
somycin $10 \mu \mathrm{gL}^{-1}$ (A) and 0.1\% DMSO (DMSO) were used as positive and negative controls, respectively. 

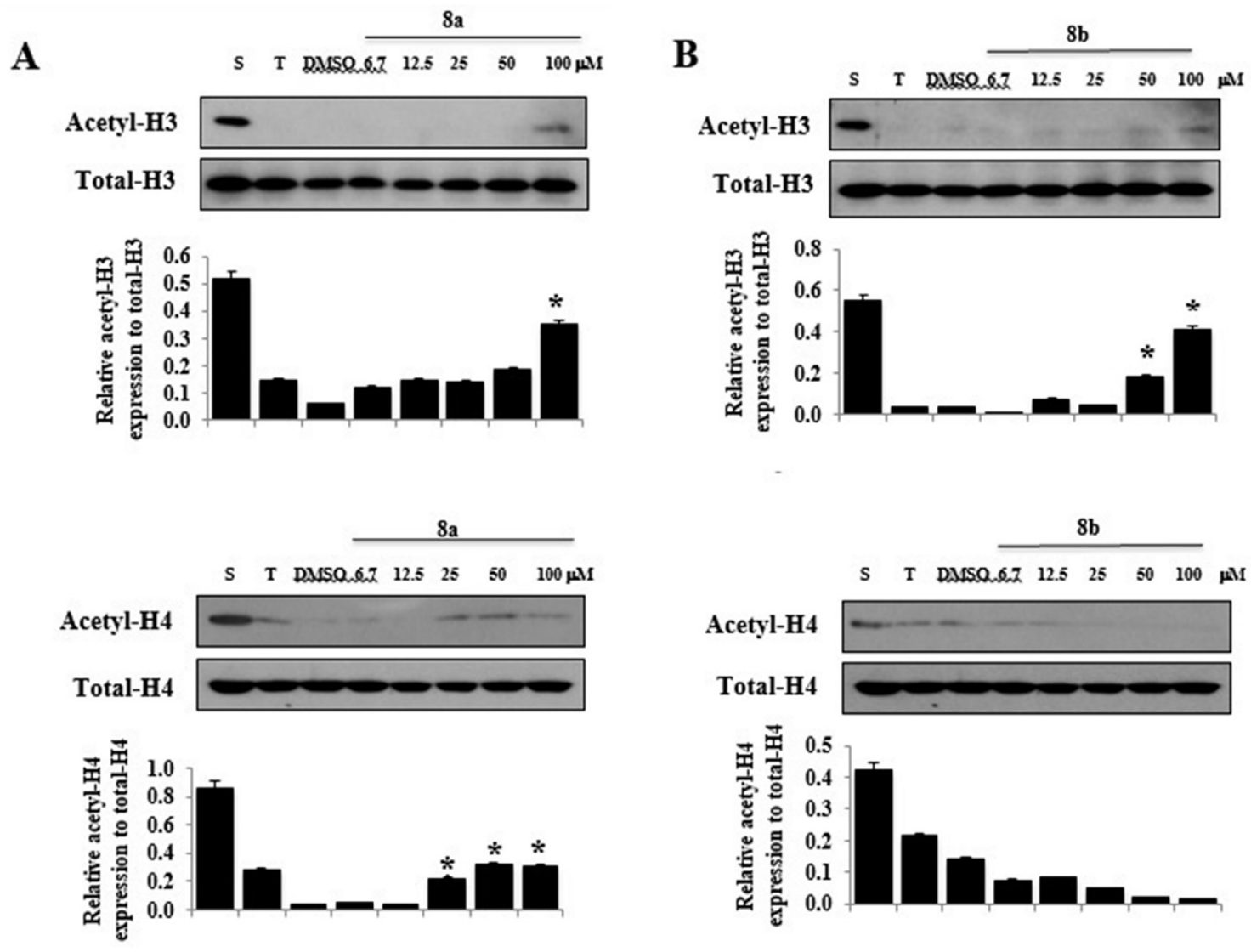

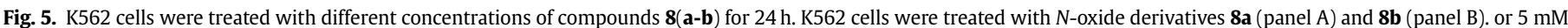

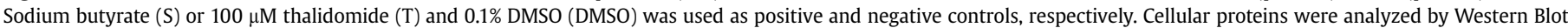

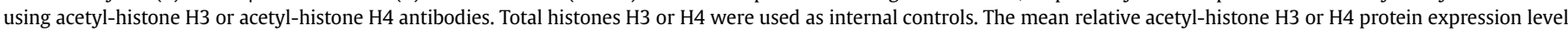

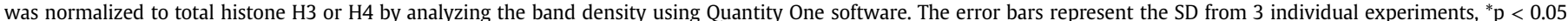

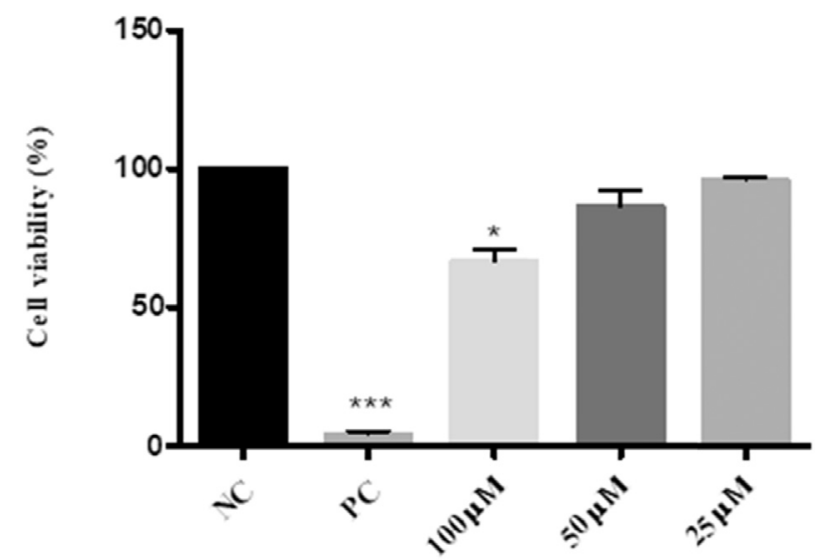

Fig. 6. Cytotoxicity of compound $\mathbf{8 b}$ (cell viability) assessed in CHO-K1 cells by XTT assay. CHO-K1 were treated with compound $\mathbf{8 b}$ or $3 \mu \mathrm{g} \mathrm{mL}^{-1}$ doxorubicin (PC). Columns indicate the mean value of cell viability. NC (negative control) was considered $100 \%$ cell viability (Ham-F10+D-MEM medium with DMSO $0.5 \%$ ). Bars indicate the standard error. ${ }^{* * *}=\mathrm{p}<0.0001$ in relation to $\mathrm{NC} ;{ }^{*}=\mathrm{p}<0.05$ in relation to $\mathrm{NC}$. Dunnett's test.

8(a-b) and 11(b-c) inhibited lipopolysaccharide-induced TNF- $\alpha$ production at levels ranging from 41.0 to $99.9 \%$, with doses inferior to that used for thalidomide. Compounds $\mathbf{5 b}$ and $\mathbf{1 1} \mathbf{b}$ did not reduce the TNF- $\alpha$ levels at the tested concentrations. Compound 11c exhibited a high efficacy for reducing TNF- $\alpha$ production compared to the other synthesized compounds (Table 3).

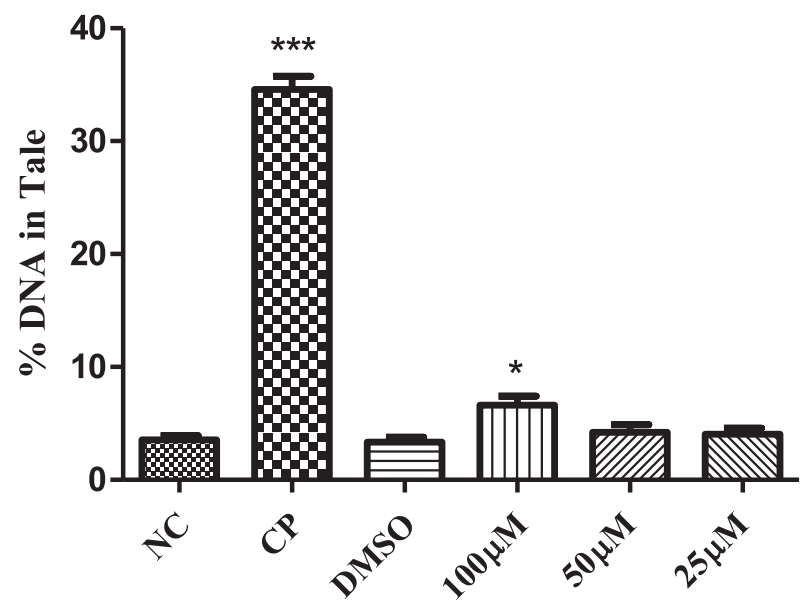

Fig. 7. Genotoxicity of compound $\mathbf{8 b}$ at different concentration evaluated by the Comet Assay. Positive controls (PC) were cells treated with hydrogen peroxide $\left(80 \mu \mathrm{mol} \mathrm{L}^{-1}\right)$ NC (negative control) were cells treated with $2 \%$ DMSO. Columns indicate the mean value of the percentage of DNA found in the nucleoid tail. Bars indicate the standard error. ${ }^{* * *}=\mathrm{p}<0.0001$ in relation to $\mathrm{NC} ;{ }^{*}=\mathrm{p}<0.05$ in relation to NC. Dunnett's test.

\subsection{Gamma-globin expression}

The most promising compounds, $\mathbf{8 a}$ and $\mathbf{8 b}$, were evaluated to determine their capacity to induce gamma-globin expression in K562 cells. These cells present many similarities to the 
erythrocytes, such as membrane glycoproteins and glycophorin A synthesis, being extensively used as experimental model for screening of globin gene regulatory compounds [35-37]. K562 cells were treated with each compound at $6.7,12.5,25,50$ and $100 \mu \mathrm{M}$ or the control hydroxyurea (HU) $(100 \mu \mathrm{M})$ for $48 \mathrm{~h}$ and $96 \mathrm{~h}$. The $\gamma$ globin levels were determined by Western blot analysis. An increase of $\gamma$-globin levels was detected in K562 cells $48 \mathrm{~h}$ after treatment with compound 8a at 6.7 and $12.5 \mu \mathrm{M}$. We also found an induction of $\gamma$-globin production after $96 \mathrm{~h}$ of treatment at $100 \mu \mathrm{M}$ (Fig. 3A).

For compound $\mathbf{8 b}$, a significant increase in $\gamma$-globin expression compared with the negative control was observed after $96 \mathrm{~h}$ of treatment at concentration of 25,50 and $100 \mu \mathrm{M}$ (Fig. 3B). Compound $\mathbf{8 b}$ was more active than $\mathbf{8 a}$ at increasing $\gamma$-globin production.

To assess the mechanism by which compounds $\mathbf{8 a}$ and $\mathbf{8 b}$ act on $\gamma$-globin production, we studied the effect of these compounds on the phosphorylation of the p38 MAPK protein levels by Western blot analysis. Phosphorylation of p38 MAPK was not observed in K562 cells treated with any one of those compounds (Fig. 4A-B).

We also evaluated whether the $N$-oxide derivatives were able to modulate the level of acetylated histone $\mathrm{H} 3$ and $\mathrm{H} 4$ during $\mathrm{HbF}$ induction. Protein lysates from K562 cells treated with these compounds or vehicle control (DMSO) for $24 \mathrm{~h}$ were analyzed by Western blot using anti-acetyl histone $\mathrm{H} 3$ and $\mathrm{H} 4$ antibodies. As shown in Fig. 5A, significant activation of histone $\mathrm{H} 3$ acetylation was detected in K562 cells treated with compound 8a at $100 \mu \mathrm{M}$ (Fig. 5B). In addition, we found that this compound increased histone $\mathrm{H} 4$ acetylation compared with the negative control $(0.1 \%$ DMSO-treated cells) (Fig. 5B). Compound $\mathbf{8 b}$ showed a level of acetylation of the histone $\mathrm{H} 3$ protein that was comparable with the negative control, but no difference of histone $\mathrm{H} 4$ acetylation between this compound and DMSO was detected in K562 cells (Fig. 5A-B). Thus, compound $\mathbf{8 b}$ affects the acetylation of histone $\mathrm{H} 3$, resulting in increased $\gamma$-globin levels. These results suggest that acetylation of histone $\mathrm{H} 3$ and/or $\mathrm{H} 4$ is involved in the up-regulation of $\gamma$-globin production induced by both compounds.

\subsection{In vitro cytotoxicity, genotoxicity and mutagenicity studies}

The most promising compound $\mathbf{8 b}$ was further evaluated regarding its ability to induce cytotoxicity, genotoxicity and mutagenicity in CHO-K1 cells. CHO cell line has been widely used for studies that assess cytotoxicity and genotoxicity, besides being recommended by Organization for Economic Cooperation and Development (OECD) for genotoxicity screening [38,39].

The cytotoxicity of compound $\mathbf{8 b}$ was evaluated by XTT method [40] (Fig. 6). At high concentration $(100 \mu \mathrm{M})$, compound $\mathbf{8 b}$ exhibited cytotoxic effect by reducing the cell viability up to $30 \%$; however, at low concentrations ( 50 and $25 \mu \mathrm{M}$ ) compound $\mathbf{8 b}$ did not present significant difference related to the negative control, and decreased the cell viability at only 14 and 4\%, respectively.

The Single Cell Gel or Comet Assay is able to detect DNA singlestrand breaks (SSB), alkali-labile sites, crosslinkings, and SSB associated with incomplete excision repair site. [41,42] Fig. 7 shows the results of genotoxicity expressed as percentage of DNA in Tail for compound $\mathbf{8 b}$ evaluated at 100,50 and $25 \mu \mathrm{M}$. Only at $100 \mu \mathrm{M}$, it was observed very low genotoxic effect compared to positive control; however, this result was not confirmed in the Tail Moment assay (Supplementary Figure S2).

Cytokinesis-block micronucleus assay (CBMN) [43] was performed as an additional assay to evaluate mutagenicity for compound $\mathbf{8 b}$. The results shows the Nuclear Division Index (NDI), frequency of binucleate cells with micronucleus (FBMN) and frequency of micronucleus (FMN) in the presence and absence of compound 8b (Table 4). The NDI was similar among all groups ( $p>0.05$, Dunn's Test), indicating that the exposure of CHO-K1 to the different concentrations of $\mathbf{8 b}$ and positive control did not induce nuclear division arrest and not interfere in the cell division. In addition, the assay reveals that compound $\mathbf{8 b}$ was not mutagenic at all concentrations tested.

\section{Table 4}

Mean value and standard error (SE) of Nuclear Division Index (NDI), Frequency of Micronucleus Binucleated Cells (FBMN) and Frequency of Micronucleus (FMN) obtained from each treatment.

\begin{tabular}{llll}
\hline Treatment & NDI Mean \pm SE & FBMN Mean \pm SE & FMN Mean \pm SE \\
\hline NC & $1.703 \pm 0.004$ & $20.67 \pm 1.453$ & $24.7 \pm 2.404$ \\
PC & $1.683 \pm 0.003$ & $107 \pm 2.646^{*}$ & $161.3 \pm 4.410^{*}$ \\
DMSO & $1.701 \pm 0.002$ & $22.33 \pm 1.453$ & $26 \pm 1.202$ \\
100 & $1.697 \pm 0.008$ & $38 \pm 1.155$ & $44 \pm 1.528$ \\
50 & $1.690 \pm 0.006$ & $32.33 \pm 0.882$ & $38 \pm 1$ \\
25 & $1.691 \pm 0.006$ & $29.33 \pm 1.764$ & $34.7 \pm 1.667$ \\
\hline
\end{tabular}

Cells were exposed for $24 \mathrm{~h}$ to compound $\mathbf{8 b}$ in three concentrations $(100,50$, $25 \mu \mathrm{M}$ ), or $2 \%$ DMSO. Negative control (NC) was culture flasks with culture medium supplemented with $10 \%$ FBS in the absence of any material (untreated controls). Positive control (PC) was treated with doxorubicin $\left(0.3 \mu \mathrm{g} \mathrm{mL}^{-1}\right){ }^{*} \mathrm{p}<0.05$ in relation to NC. Dunn's Test.

\section{Discussion}

HU remains the main drug approved by the FDA for ameliorating SCD symptoms, despite of its lack of efficacy in some patients and serious adverse effects during long-term treatment [11,44]. Therefore, it is important to develop new safe and effective drugs. Among the strategies used to discover potential drugs for the treatment of SCD, those aimed at increasing fetal hemoglobin seem to be beneficial in preventing complications related to the disease [12,45]. Increased levels of $\mathrm{HbF}$ interfere with sickle hemoglobin $\mathrm{S}$ polymerization, reduce the severity of the disease and increase the lifespan of patients.

Immunomodulatory imide drugs, including thalidomide and pomalidomide, have been reported to increase $\mathrm{HbF}$ in vitro and in vivo. [46-48] Thalidomide increases gamma-globin mRNA expression without altering beta-globin expression. The drug also increases reactive oxygen species (ROS) and activates the p38 mitogen-activated protein kinase (MAPK) signaling pathway along with histone H4 hyperacetylation [16]. A role for p38 MAPK in gamma-globin regulation has been reported in human erythroid progenitors and K562 erythroleukemia cells. Moreover, thalidomide exhibits analgesic and anti-inflammatory activities that are beneficial to SCD patients [49]. Therefore, thalidomide is an interesting prototype for further molecular modifications to discovery new compounds to ameliorate SCD symptoms.

Furoxan (1,2,5-oxadiazole 2-oxide) derivatives are widely known for their capacity to release NO. Nitric oxide is an important mediator of cell functions and has various effects, including vasodilatation, inhibition of platelet aggregation, and reduction of adhesive molecules. This mediator also stimulates the expression of the gamma globin gene and consequently increases the production of HbF. This mechanism seems to involve soluble guanylyl cyclase (sGC), which increases the expression of $\gamma$-globin in erythroleukemic cells and primary erythroblasts. Elevated levels of sGC were observed in erythroid progenitors expressing $\gamma$-globin compared to $\beta$-globin [26]. NO/cGMP plays an important role in $\gamma$ globin expression by activating transcription factors, including cJun and c-Fos, which bind to hypersensitive site 2 in the $\beta$-locus control region [50]. This mediator also increases the binding of Sp-1 to the CACCC box, activating $\gamma$-globin gene expression [13]. 
Because the beneficial effect of $\mathrm{HU}$, which is related in part to its capacity to generate NO [50-52], it was hypothesized that the combination of thalidomide and a NO-donor subunit could enhance the efficacy and potency to increase gamma-globin expression and fetal hemoglobin, making it an alternative to hydroxyurea for SCD treatment.

In this work, we demonstrated that compounds $\mathbf{5}(\mathbf{a}-\mathbf{b})$, and $\mathbf{8}(\mathbf{a}-\mathbf{b})$ released nitric oxide at different levels in the presence of $\mathrm{L}_{-}$ cysteine. Indeed, preliminary chemical stability studies in the presence of L-cysteine suggest that coumpound $\mathbf{8 b}$ is metabolized to an opened ring nitroso intermediate (results not shown). These observations are in according to experimental data from literature [24]. Compounds 8(a-b), containing the group 3phenylsulfonylfuroxan, were the most potent at releasing $\mathrm{NO}$ at levels ranging from $23.7 \%-30.1 \%$, whereas the other compounds produced values of NO ranging from $16.4 \%-17.1 \%$ ( $\mathrm{mol} / \mathrm{mol})$. This different profile of NO production is related in part to the presence of electron-withdrawing substituents at the 3-position. Therefore, it was found that phenylsulfonyl, a strong electron-withdrawing substituent, was more active at releasing NO than phenyl and methyl groups [20,53]. Benzofuroxan derivatives (11a-c) did not release NO in this assay. The concentration of all compounds $(100 \mu \mathrm{M})$ in the Griess assay was determined based on its water solubility and limit of detection of UV-spectrophotometer.

Intravascular hemolysis reduces endothelial NO bioavailability and promotes inflammatory and proadhesive states in the endothelium favoring vaso-occlusion and prothrombotic events [3]. In addition, tissue injury and platelet activation produce a state of hypercoagulability in SCD patients [39]. In humans, antagonists of the $\mathrm{P}_{2} \mathrm{Y}_{12}$ adenosine diphosphate (ADP) receptor have shown the capacity to reduce the hypercoagulability state in $S C D$, preventing the vaso-occlusion process [6,54]. Prasugrel, for example, decreased platelet adherence to monocytes and neutrophils, reducing the cell-platelet aggregate size [55]. Plasma ADP levels are not only increased in humans but also in animals. For example, Berkeley sickle cell mice exhibited a 2.7-fold increase in plasma ADP compared to control mice [56]. Therefore, we evaluated the capacity of compounds $\mathbf{5}(\mathbf{a}-\mathbf{b}), \mathbf{8}(\mathbf{a}-\mathbf{b})$, and $\mathbf{1 1}(\mathbf{a}-\mathbf{b})$ to inhibit the platelet aggregation induced by ADP. All of the compounds, except 11a, exhibited a capacity to inhibit platelet aggregation. Compounds $\mathbf{8 a}$ and $\mathbf{8 b}$ were the most promising inhibitors of ADPinduced platelet aggregation, with rates of $84.0 \%$ and $76.1 \%$, respectively. These interesting effects should be attributed not only to the antagonism of $\mathrm{P}_{2} \mathrm{Y}_{12}$ ADP receptor but also to the ability to release nitric oxide by the compounds.

Nitric oxide also plays an important role in decreasing platelet aggregation due to its involvement in the NO/sGC/cGMP/PKG system [57]. NO-donor compounds, such as organic nitrate esters, exhibited an antithrombotic effect and inhibited platelet aggregation in vitro and in vivo [27,58].

Pain is one of the most common reasons for hospital admissions in people with SCD. It has been reported that both neuropathic and nociceptive components are present in vaso-occlusive pain [59]. In addition, the pro-inflammatory state present in SCD patients exacerbates this symptom. Leukocyte activation and overexpression of adhesion molecules increase pro-inflammatory cytokines, such as TNF- $\alpha$, IL-1 $\beta$ and IL-8, aggravating the vaso-occlusive process and acute pain [6]. Ribeiro and co-workers described that thalidomide exhibits analgesic and anti-inflammatory effects using both in vitro and in vivo models. This drug decreased the writhing nociceptive response in mice due to its capacity to inhibit TNF- $\alpha$ [60]. Therefore, to investigate the analgesic effect of the synthesized compounds, we used the classical model of abdominal constriction in mice induced by acetic acid [34]. Compound $\mathbf{8 b}$ was identified as the most active molecule, reducing acetic acid-induced abdominal constrictions by $50.1 \%$. Compounds $\mathbf{5 b}, \mathbf{8}(\mathbf{a}-\mathbf{b})$ and $\mathbf{1 1}(\mathbf{b}-\mathbf{c})$ showed significant antinociceptive activity compared to dipyrone.

Based on these results, we hypothesized that the analgesic effect could be attributed to the TNF- $\alpha$ inhibition caused by the compounds. It is known that TNF- $\alpha$ plays an important role in nociceptive signaling and SCD patients exhibit high levels of this proinflammatory cytokine [7,61]. In our study, we found that the most analgesic compounds inhibited lipopolysaccharide-induced TNF- $\alpha$ production. Specifically, compounds $\mathbf{8}(\mathbf{a}-\mathbf{b})$ and $\mathbf{1 1}(\mathbf{b}-\mathbf{c})$ exhibited activity superior to that of thalidomide, showing a correlation between pain and TNF- $\alpha$ inhibition.

Because of the balance among the NO-donor, anti-platelet and analgesic effects seems to be beneficial to SCD patients, we selected compounds $\mathbf{8 a}$ and $\mathbf{8 b}$ for additional studies to characterize their capacity to induce $\gamma$-globin production in K562 cells. $\gamma$-globin is a fetal hemoglobin tetramer that is present during fetal development. After birth, $\mathrm{HbF}$ is gradually replaced by $\mathrm{HbA}(\alpha 2 \beta 2)$. $\mathrm{HbF}$ induction is a promising strategy to reduce the clinical severity of SCD [13,62]. Indeed, the beneficial effects of HU have been associated with its capacity to increase $\gamma$-globin expression.

We observed that compound 8a increases $\gamma$-globin expression in K562 cells only after $96 \mathrm{~h}$ of treatment at $100 \mu \mathrm{M}$ compared with the negative control. By contrast, compound $\mathbf{8 b}$ increased $\gamma$-globin expression at concentrations of 25,50 and $100 \mu \mathrm{M}$ for $96 \mathrm{~h}$. It has been shown that thalidomide induces $\gamma$-globin gene expression by increasing reactive oxygen species-mediated p38 mitogenactivated protein kinase (p38 MAPK) signaling and histone H4 acetylation [16]. MAPKs regulate gene expression through phosphorylation of transcription factors [63].

To assess the mechanism by which compounds 8a and $\mathbf{8 b}$ regulate $\gamma$-globin, we studied the effects of these compounds on the phosphorylation of the p38 MAPK protein levels. However, no phosphorylation of p38 MAPK was observed in K562 cells treated with each of these compounds. Thus, we concluded that the upregulation of $\gamma$-globin mediated by these analogues does not act through p38 MAPK phosphorylation as observed for thalidomide.

To evaluate whether these compounds modulate $\gamma$-globin induction via histone acetylation, we determined the level of acetylated histone $\mathrm{H} 3$ and $\mathrm{H} 4$ in $\mathrm{K} 562$ cells lysates. A significant activation of acetylated histones $\mathrm{H} 3$ and $\mathrm{H} 4$ was detected in cells treated with compound 8a compared with the negative control (DMSO). However, compound $\mathbf{8 b}$ only acted on the acetylation of histone $\mathrm{H} 3$. These results indicate that acetylation of histone $\mathrm{H} 3$ and/or $\mathrm{H} 4$ is involved during the up-regulation of $\gamma$-globin production induced by these compounds.

In vitro cytotoxic, genotoxic and mutagenic studies using $\mathrm{CHO}-$ $\mathrm{K} 1$ cells were performed for compound $\mathbf{8 b}$. In general manner, the results showed that compound $\mathbf{8 b}$ was not cytotoxic, genotoxic and mutagenic. These results corroborates with previous studies that shows that phthalimide derivatives were not mutagenic $[10,64]$. In part, this effect can be attributed to the absence of the glutarimide ring in compound $\mathbf{8 b}$. The glutarimide subunit is responsible for teratogenic effects of thalidomide due to its ability to bind in the active site of the Cereblon damaged DNA-binding protein 1 (CRBN-DDB1) E3 ubiquitin ligase complex causing cytotoxic and teratogenic effects [65].

All of these results demonstrate that $\mathrm{N}$-oxide derivatives present analgesic and antiplatelet activity, TNF- $\alpha$ inhibition effect and capacity to induce $\gamma$-globin expression representing a novel approach for treating sickle cell disease symptoms.

\section{Conclusions}

A novel series of $\mathrm{N}$-oxide derivatives, $\mathbf{5}(\mathbf{a}-\mathbf{c}), \mathbf{8}(\mathbf{a}-\mathbf{b})$, and 11(a-b), was synthesized and characterized by ${ }^{1} \mathrm{H}$ and ${ }^{13} \mathrm{C}$ NMR, 
mass spectrometry and IR spectroscopy. All of the compounds demonstrated NO-donor properties at levels ranging from 0 to 30.1\%. Compounds $\mathbf{5 b}, \mathbf{8}(\mathbf{a}-\mathbf{b})$ and $\mathbf{1 1}(\mathbf{b}-\mathbf{c})$ showed significant antinociceptive activity compared to dipyrone. However, compound $\mathbf{8 b}$ was the most active antinociceptive compound, reducing acetic acid-induced abdominal constrictions by $50.1 \%$. The analgesic effect seems to be related to TNF- $\alpha$ inhibition. In vitro, compounds $\mathbf{8}(\mathbf{a}-\mathbf{b})$ and $\mathbf{1 1}(\mathbf{b}-\mathbf{c})$ reduced TNF- $\alpha$ levels. Compounds 8a and $\mathbf{8 b}$ were the most promising inhibitors of ADP-induced platelet aggregation, with rates of $84.0 \%$ and $76.1 \%$, respectively. Both of these compounds also increased $\gamma$-globin expression after $96 \mathrm{~h}$ of treatment in $\mathrm{K} 562$ cells. The results indicated that the mechanism involved in this up-regulation of $\gamma$-globin is related to the acetylation of histone $\mathrm{H} 3$ and $\mathrm{H} 4$ by these compounds. Specifically, the most promising compound $\mathbf{8 b}$ was not genotoxic and mutagenic using CHO-K1 cells. Therefore, phenylsulfonyl furoxan derivative (8b) is a promising novel prototype for designing new compounds that will be useful for treating SCD symptoms.

\section{Experimental section}

\subsection{Chemistry. General information}

Reagents and solvents were purchased from commercial suppliers at reagent purity grade and were used without any further purification. Dry solvents used in the reactions were obtained by distillation of technical grade materials over appropriate dehydrating agents. Thin-layer chromatography (TLC), precoated with silica gel 60 (HF-254; Merck) to a thickness of $0.25 \mathrm{~mm}$, was used for monitoring all reactions. The plates were revealed under UV light (265 nm). All compounds were purified on a chromatography column with silica gel (60 A pore size, $35-75-\mu \mathrm{m}$ particle size) and the following solvents were used as mobile phase: dichloromethane, hexane, ethyl acetate and petroleum ether. In addition, the purity analyzed by HPLC for all tested compounds was superior to $98 \%$. Melting points $(\mathrm{mp})$ were determinate in open capillary tubes using an electrothermal melting point apparatus (SMP3; Bibby Stuart Scientific). Infrared (IR) spectroscopy (KBr disc) were performed on an FTIR-8300 Shimadzu spectrometer, and the frequencies are expressed per $\mathrm{cm}^{-1}$. The nuclear magnetic resonance (NMR) for ${ }^{1} \mathrm{H}$ and ${ }^{13} \mathrm{C}$ of all compounds were scanned on a Bruker Fourier with Dual probe ${ }^{13} \mathrm{C} /{ }^{1} \mathrm{H}(300-\mathrm{MHz})$ NMR spectrometer using dimethyl sulfoxide (DMSO- $d_{6}$ ), as solvent. Chemical shifts were expressed in parts per million ( $\mathrm{ppm}$ ) relative to tetramethylsilane. The signal multiplicities are reported as singlet (s), doublet (d), doublet of doublet (dd), and multiplet (m). Mass spectrometry of all of the compounds was performed with a model micrOTOF electrospray ionization-time of flight (ESI-TOF) (Bruker Daltonics) spectrometer, and the spectra were accumulated for $60 \mathrm{~s}$. The compounds were injected at a flow rate of $300 \mu \mathrm{l} / \mathrm{h}$, a capillary voltage of $4.5 \mathrm{kV}$, a cone voltage of $120 \mathrm{~V}$, and a desolvation temperature at $180^{\circ} \mathrm{C}$. The spectra were obtained in positive mode and acquired over range of $200-800 \mathrm{~m} / \mathrm{z}$.

\subsection{General procedures for the synthesis of N-oxide derivatives 5(a- b), $8(a-b)$, and 11(a-c)}

Compounds 1, 6(a-b) and 9 were synthesized according to a previously described methodologies [18,54,59].

An equivalent amount of furoxan derivatives $1,6(\mathbf{a}-\mathbf{b})$ or 9 $(0.01 \mathrm{~mol})$ was added to a solution of hydrazide derivatives $(\mathbf{2} \mathbf{a}-\mathbf{b})$ $(0.01 \mathrm{~mol})$ in $15 \mathrm{~mL}$ of ethanol in the presence of a catalytic amount of glacial acetic acid. The reaction was stirred for $7-24 \mathrm{~h}$ at room temperature and monitored by TLC. Subsequently, the solvent was evaporated under reduced pressure. The precipitate was collected by filtration, washed with cold water, and dried under vacuum to give the derivatives $\mathbf{3}(\mathbf{a}-\mathbf{b}), \mathbf{7}(\mathbf{a}-\mathbf{b})$, and $\mathbf{1 0}(\mathbf{a}-\mathbf{c})$ with yields ranging from 34 to $75 \%$. In the last step, phthalic anhydride (4) $(0.001 \mathrm{~mol})$ and the derivatives $\mathbf{3}(\mathbf{a}-\mathbf{b}), \mathbf{7}(\mathbf{a}-\mathbf{b})$, or $\mathbf{1 0}(\mathbf{a}-\mathbf{c})$ $(0.001 \mathrm{~mol})$ were condensed using 1-ethyl-3-(3dimethylaminopropyl)carbodiimide (EDC) $(0,0015 \mathrm{~mol})$ and 4dimethylaminopyridine (DMAP) using dimethylformamide as the solvent. The $\mathrm{N}$-oxide derivatives were obtained at yields ranging from 25 to $55 \%$ after purification by column chromatography (flash silica, eluent: $70 \%$ ethyl acetate, $30 \%$ hexane).

\subsection{1. $\quad$ '-((2-(l1-oxidanyl)-4-phenyl-1,2l4,5-oxadiazol-3-yl)} methylene)-2-(1,3-dioxoisoindolin-2-yl)benzohydrazide (5a)

Yield 53\%; mp: $250-251^{\circ} \mathrm{C}$. IR ( $\nu_{\max } \mathrm{cm}^{-1} \mathrm{KBr}$ pellets): 3253 $(\mathrm{N}-\mathrm{H}), 1780,1710(\mathrm{C}=\mathrm{O}$ imide $) ; 1656(\mathrm{C}=\mathrm{O}$ amide $) ; 1602(\mathrm{CH}=\mathrm{N})$; 1379 (C-N); $1269(\mathrm{~N}-\mathrm{O}) .{ }^{1} \mathrm{H}$ NMR (300 Mz, DMSO-d $)$ ) : 7.17-7.50 $(3 \mathrm{H}, \mathrm{m}) ; 7.54-7.67$ (3H, m); 7.73-7.87 (3H, m); 7.94-7.96 (4H, m); $8.23(1 \mathrm{H}, \mathrm{s}), 12.43(1 \mathrm{H}, \mathrm{s}) \mathrm{ppm} .{ }^{13} \mathrm{C}$ NMR (DMSO-d 6 ) $\delta: 113.0 ; 123.9$; 124.0; 129.1; 129.3; 130.9; 131.9; 132.4; 133.5; 135.3; 156.5; 162.0; 167.3 ppm. MS/ESI $m / z:[\mathrm{M}]^{+}$476, [M -Na]+ 453 (54\%).

\subsubsection{3-((2-(4-(1,3-dioxoisoindolin-2-yl)benzoyl)hydrazono) methyl)-4-phenyl-1,2,5-oxadiazole 2-oxide (5 b)}

Yield 55\%; mp: $205-208^{\circ} \mathrm{C}$. IR ( $\nu_{\max } \mathrm{cm}^{-1} \mathrm{KBr}$ pellets): 3230 $(\mathrm{N}-\mathrm{H}), 1740,1712(\mathrm{C}=\mathrm{O}$ imide $) ; 1651(\mathrm{C}=\mathrm{O}$ amide $) ; 1606(\mathrm{CH}=\mathrm{N})$; 1379 (C-N); 1269 (N-O). ${ }^{1} \mathrm{H}$ NMR (300 Mz, DMSO-d d $) \delta: 7.61(2 \mathrm{H}, \mathrm{d}$, $J=7,7 \mathrm{~Hz}) ; 7.66-7.82(3 \mathrm{H}, \mathrm{m}) ; 7.96-7.94(2 \mathrm{H}, \mathrm{m}) ; 8.02-8.00(4 \mathrm{H}$, m) $8.06(\mathrm{~d}, 2 \mathrm{H}, J=7,7 \mathrm{~Hz}) 8.41,(1 \mathrm{H}, \mathrm{s}), 12.37(1 \mathrm{H}, \mathrm{s}) \mathrm{ppm} .{ }^{13} \mathrm{C} \mathrm{NMR}$ (DMSO-d $\left.)_{6}\right)$ : $114.3 ; 125.0 ; 127.1 ; 128.5 ; 129.8 ; 130.2 ; 130.5 ; 133.0$; $134.9 ; 136.3 ; 157.5 ; 160.0 ; 168.2$ MS/ESI $m / z:[\mathrm{M}]^{+} 476,[\mathrm{M}-\mathrm{Na}]^{+}$ $453(84 \%)$.

\subsubsection{4-(3-((2-(4-(1,3-dioxoisoindolin-2-yl)benzoyl)hydrazono)} methyl)phenoxy)-3-(phenylsulfonyl)-1,2,5-oxadiazole 2-oxide (8a)

Yield 25\%; mp: $202-204^{\circ} \mathrm{C}$. IR ( $\nu_{\max } \mathrm{cm}^{-1} \mathrm{KBr}$ pellets): 3292 $(\mathrm{N}-\mathrm{H}), 1782(\mathrm{C}=\mathrm{O}$ imide $) ; 1650(\mathrm{C}=\mathrm{O}$ amide $) ; 1607(\mathrm{CH}=\mathrm{N}) ; 1399$ (C-N); ${ }^{1} \mathrm{H}$ NMR (300 Mz, DMSO-d 6 ) $\delta: 7.56(2 \mathrm{H}, \mathrm{m}) ; 7.73-7.64(3 \mathrm{H}$, m); 7.85-7.77 (3H, m); 7.96-7.92 (3H, m); $8.09(4 \mathrm{H}, \mathrm{m}) ; 8.50(1 \mathrm{H}$, s), $12.09(1 \mathrm{H}, \mathrm{s}) \mathrm{ppm} .{ }^{13} \mathrm{C}$ NMR (DMSO-d 6 ) $\delta: 111.7 ; 118.1 ; 121.5$; 124.5; 127.6; 128.7; 129.0; 130.5; 131.9; 136.7; 137.3; 147.1, 153.3; 161.2, 167.2 ppm. MS/ESI $m / z:[\mathrm{M}]^{+} 632,08,{\text { [M }-\mathrm{Na}]^{+}}^{+} 609$ (88\%).

\subsubsection{4-(4-((2-(4-(1,3-dioxoisoindolin-2-yl)benzoyl)hydrazono)} methyl)phenoxy)-3-(phenylsulfonyl) 1,2,5-oxadiazole 2-oxide ( $8 \mathrm{~b}$ )

Yield 30\%; mp: $220-223^{\circ} \mathrm{C}$. IR ( $\nu_{\max } \mathrm{cm}^{-1} \mathrm{KBr}$ pellets): 3268 $(\mathrm{N}-\mathrm{H}), 1774(\mathrm{C}=\mathrm{O}$ imide $) ; 1650(\mathrm{C}=\mathrm{O}$ amide $) ; 1604(\mathrm{CH}=\mathrm{N}) ; 1388$ (C-N). ${ }^{1} \mathrm{H}$ NMR (300 Mz, DMSO-d $\left.d_{6}\right) \delta: 7.54(2 \mathrm{H}, \mathrm{m}) ; 7.64(2 \mathrm{H}, \mathrm{d}$, $J=7.7 \mathrm{~Hz}) ; 7.74-7.80(2 \mathrm{H}, \mathrm{m}) ; 7.86-7.89(2 \mathrm{H}, \mathrm{m}) ; 7.94-7.90(3 \mathrm{H}$, m); 7.98-8.01 (2H, m); 8.04-8.07 (4H, m); $8.49(1 \mathrm{H}, \mathrm{s}), 12.05(1 \mathrm{H}, \mathrm{s})$ ppm. ${ }^{13}$ C NMR (DMSO-d 6 ) $\delta: 111.4 ; 120.2 ; 123.6 ; 127.2 ; 128.3 ; 128.6$; 129.0; 130.1; 132.7; 130.1; 134.9; 136.4; 136.9; 146.8; 158.2; 162.8; 166.8. MS/ESI $m / z:[\mathrm{M}]^{+} 632,08,[\mathrm{M}-\mathrm{Na}]^{+} 609$ (92\%).

\subsubsection{6-((2-(2-(1,3-dioxoisoindolin-2yl)benzoyl)hydrazono)} methyl)benzo [1,2,5]oxadiazole 1-oxide (11a)

Yield 43\%; mp: $250-251^{\circ} \mathrm{C}$. IR ( $\nu_{\max } \mathrm{cm}^{-1} \mathrm{KBr}$ pellets): 3282 ( $\mathrm{N}-\mathrm{H}$ ); 1708 ( $\mathrm{C}=\mathrm{O}$ imide); 1685 ( $\mathrm{C}=\mathrm{O}$ imide), 1654 ( $\mathrm{C}=\mathrm{O}$ amide); $1614(\mathrm{CH}=\mathrm{N}) ; 1381(\mathrm{C}-\mathrm{N}) .{ }^{1} \mathrm{H}$ NMR (300 Mz, DMSO-d 6$) \delta: 7.90(3 \mathrm{H}$, $\mathrm{m}) ; 7.88(2 \mathrm{H}, \mathrm{m}) ; 7.77(6 \mathrm{H}, \mathrm{m}) ; 8.40(1 \mathrm{H}, \mathrm{s}) ; 12.45(1 \mathrm{H}, \mathrm{s}) \mathrm{ppm} .{ }^{13} \mathrm{C}$ NMR (DMSO-d $\left.d_{6}\right) \delta: 117.0 ; 118.0 ; 123.0 ; 125.0 ; 129.2 ; 131.0 ; 134.5$; 159.0. MS/ESI $m / z:[\mathrm{M}]^{+} 320,09,[\mathrm{M}-\mathrm{Na}]^{+} 297$ (42\%).

\subsubsection{6-((2-(3-(1,3-dioxoisoindolin-2yl)benzoyl)hydrazono)} methyl)benzo [1,2,5]oxadiazole 1-oxide (11 b)

Yield 30\%; mp: $218^{\circ} \mathrm{C}$. IR ( $\nu_{\max } \mathrm{cm}^{-1} \mathrm{KBr}$ pellets): $3032(\mathrm{~N}-\mathrm{H})$, 
1772 ( $\mathrm{C}=\mathrm{O}$ imide); 1718 ( $\mathrm{C}=\mathrm{O}$ imide), 1635( $\mathrm{C}=\mathrm{O}$ amide); 1616 $(\mathrm{CH}=\mathrm{N}) ; 1398(\mathrm{C}-\mathrm{N}) ;{ }^{1} \mathrm{H}$ NMR $\left(300 \mathrm{Mz}\right.$, DMSO-d $\left.{ }_{6}\right) \delta: 7.90(3 \mathrm{H}, \mathrm{m})$; $7.88(2 \mathrm{H}, \mathrm{m}) ; 7.92(1 \mathrm{H}, \mathrm{m}) ; 7.94(1 \mathrm{H}, \mathrm{m}) ; 7.98(1 \mathrm{H}, \mathrm{m}) ; 8.06(1 \mathrm{H}, \mathrm{s})$; 8.13-8.18 (3H, m); $11.60(1 \mathrm{H}, \mathrm{s})$ ppm. ${ }^{13} \mathrm{C}$ NMR (DMSO-d 6 ) $\delta: 117.0$; $118.0 ; 123.0 ; 125.0 ; 129.2 ; 131.0 ; 134.5 ; 159.0 . \mathrm{MS} / \mathrm{ESI} \mathrm{m} / \mathrm{z}:[\mathrm{M}]^{+}$ $320,09,[\mathrm{M}-\mathrm{Na}]^{+} 297$ (52\%).

\subsubsection{6-((2-(4-(1,3-dioxoisoindolin-2 yl)benzoyl)hydrazono)}

methyl)benzo [1,2,5]oxadiazole 1-oxide (11c)

Yield 50\%; mp: $218^{\circ} \mathrm{C}$. IR ( $\nu_{\max } \mathrm{cm}^{-1} \mathrm{KBr}$ pellets): $3414(\mathrm{~N}-\mathrm{H})$, $1772,1718$ ( $\mathrm{C}=\mathrm{O}$ imide $) ; 1635(\mathrm{C}=\mathrm{O}$ amide $) ; 1616(\mathrm{CH}=\mathrm{N}) ; 1400(\mathrm{C}-$ N). ${ }^{1} \mathrm{H}$ NMR (300 Mz, DMSO-d $\left.d_{6}\right) \delta: 7.86-7.88(2 \mathrm{H}, \mathrm{m}) ; 7.89-7.93$ $(5 \mathrm{H}, \mathrm{m}) ; 7.96(2 \mathrm{H}, \mathrm{dd}, J=8.0 \mathrm{~Hz}) ; 8.07(2 \mathrm{H}, \mathrm{dd}, J=8.0 \mathrm{~Hz}) ; 8,7(1 \mathrm{H}$, s), $11.70(1 \mathrm{H}, \mathrm{s}) \mathrm{ppm} .{ }^{13} \mathrm{C}$ NMR (DMSO- $\left.d_{6}\right) \delta: 118.5 ; 122.8 ; 125.0$; $129.2 ; 131.5 ; 132.7 ; 160.0 ; 195.0 . \mathrm{MS} / \mathrm{ESI} m / z:[\mathrm{M}]^{+} 320,[\mathrm{M}-\mathrm{Na}]^{+}$ 297 (54\%).

\subsection{Pharmacology}

\subsubsection{Quantification of nitrite by the Griess reaction}

Quantification of nitrite was performed according to previously published methods [20]. The yields of nitrite are expressed as \% $\mathrm{NO}_{2}^{-}(\mathrm{mol} / \mathrm{mol})$.

\subsubsection{Animals}

Adult male and female Swiss albino mice (25-35 g) and Wistar rats $(200-250 \mathrm{~g})$ were used in the experiments. They were housed in single-sex cages under a $12 \mathrm{~h}$ light/ $12 \mathrm{~h}$ dark cycle (lights on at 06:00) in a controlled-temperature room $\left(22 \pm 2^{\circ} \mathrm{C}\right)$. The animals had free access to food and water. The experiments were performed after approval by local Institutional Ethics Committee (CEUA Process No. 10/2010 and 32/2013). All experiments were performed in accordance with the current guidelines for the care of laboratory animals and the ethical guidelines for the investigation of experimental pain in conscious animals.

\subsubsection{Antiplatelet activity}

Platelet-rich plasma (PRP) was obtained from the blood of Wistar rats by centrifugation at $375 \times g$ for $10 \mathrm{~min}$ at room temperature [21]. A volume of $300 \mu \mathrm{L}$ of PRP was incubated at $37^{\circ} \mathrm{C}$ for $1 \mathrm{~min}$ with continuous stirring (900 rpm). Platelet aggregation was monitored by the turbidimetric method using a Chrono-Log aggregometer. The aggregant agent was ADP at $10 \mu \mathrm{M}$. The vehicle DMSO $(0.5 \% \mathrm{v} / \mathrm{v}$; negative control), test compounds $(100 \mu \mathrm{M})$ or acetylsalicylic acid (AAS; $100 \mu \mathrm{M}$; positive control) was added to the PRP samples 1 min before addition of the aggregating agent. The results are expressed as the percentage of inhibition and analyzed using ANOVA followed by Tukey's test.

\subsubsection{Antinociceptive activity}

The analgesic activity was evaluated in vivo using the acetic acid-induced $(0.6 \%, 0.1 \mathrm{~mL} / 10 \mathrm{~g})$ abdominal constriction model [22]. Swiss mice of both sexes (18-23 g) were used. Compounds were administered orally $(100 \mu \mathrm{mol} / \mathrm{kg})$ as a suspension in $5 \%$ arabic gum in saline (vehicle). Dipyrone $(100 \mu \mathrm{mol} / \mathrm{kg}$ ) was used as the standard drug, administered under the same conditions. An acetic acid solution was administered $i$. p. $1 \mathrm{~h}$ after the administration of each compound. Ten minutes after the acetic acid injection, the number of constrictions per animal was recorded for $20 \mathrm{~min}$. The control animals received an equal volume of vehicle. Antinociceptive activity is expressed as the percentage inhibition of the constrictions compared with those in the vehicle-treated control group. The results are expressed as the mean \pm SEM of 8 animals per group. The data were analyzed statistically with ANOVA followed by Dunnett's test at a significance level of $p<0.01$.

\subsubsection{Cellular viability and quantification of TNF- $\alpha$ levels in macrophage supernatant}

A solution of thioglycollate at $3 \%$ was administered into the peritoneal cavity of Swiss mice to stimulate macrophage migration. Three days later, the peritoneal exudates were collected, washed with $5 \mathrm{~mL}$ of sterile PBS (pH 7.4) and resuspended in RPMI-1640C medium to obtain the macrophage cells, which were counted in a Neubauer chamber (Boeco, Germany) and adjusted to $5 \times 10^{6}$ cells/ $\mathrm{mL}$ in of 96 -well microplates $(100 \mu \mathrm{L})$. Non-adherent cells (mostly neutrophils) were removed by incubating the suspension in cell culture plates for $1 \mathrm{~h}$ at $37^{\circ} \mathrm{C}$ in an atmosphere containing $5 \% \mathrm{CO}_{2}$ (Forma Scientific, Marietta, $\mathrm{OH}$ ) and discarding the supernatant. Adherent cells were incubated at $37^{\circ} \mathrm{C}$ and $5 \% \mathrm{CO}_{2}$ for $24 \mathrm{~h}$ in the presence of bacterial lipopolysaccharide (Escherichia coli $0111 \mathrm{~B}$ ) (LPS) $(10 \mathrm{mg} / \mathrm{mL})$, tested molecules thalidomide or $[\mathbf{5}(\mathbf{a}-\mathbf{b}), \mathbf{8}(\mathbf{a}-\mathbf{b})$, and 11(a-c)] or RPMI-1640C medium. After $24 \mathrm{~h}, 100 \mu \mathrm{L}$ of a solution containing 3-(4,5-dimethylthiazol-2-yl)-2,5diphenyltetrazolium bromide (MTT) $(1 \mathrm{mg} / \mathrm{mL})$ was added to each well. The plates were incubated for 3 additional hours at $37^{\circ} \mathrm{C}$ in an atmosphere containing $5 \% \mathrm{CO}_{2}$. The content was discarded, and $100 \mu \mathrm{L}$ of isopropyl alcohol was added to each well. The absorbance was measured at $540 \mathrm{~nm}$ using a BioTek ${ }^{\circledR}$ microplate reader spectrophotometer. The results are expressed as the percentage of viable cells. For quantification of the TNF- $\alpha$ levels, concentrations with a macrophage viability greater than $70 \%$ were considered. The levels of pro-inflammatory cytokine TNF- $\alpha$ were quantified in the culture supernatants of 96-well microplates by ELISA (OptEIA; BD Biosciences, San Diego, CA) according to the manufacturer's instructions. The cytokine concentrations were calculated from a standard curve of known cytokine concentrations and expressed in $\mathrm{pg} / \mathrm{mL}$. In all of the experiments, the results were expressed as the means \pm SEM. Each experiment was performed in triplicate at least three times. One-way ANOVA with Tukey's Multiple Comparison Test as a post hoc test was performed using GraphPad InStat version 3.00 for Windows 95 (GraphPad Software, San Diego, California, U.S.A.). The statistical significance was defined as a $\mathrm{p}$ value less than 0.05 .

\subsubsection{Cell cultures}

K562 cells were cultured in Dulbecco modified Eagle medium (Thermo Fisher Scientific, Cat\#11965-092, Waltham, MA) containing 10\% fetal bovine serum (Thermo Fisher Scientific, Cat\#16000044) and $1 \mathrm{X}$ penicillin-streptomycin (Thermo Fisher Scientific, Cat\#15140-148). Cells were treated with each compound at a final DMSO concentration of $0.1 \%$. Cells were cultured at $37{ }^{\circ} \mathrm{C}$ in a $5 \%$ $\mathrm{CO}_{2}$ humidified atmosphere.

5.3.6.1. Western blot analysis. K562 cells $(2 \times 105$ cells $/ \mathrm{mL})$ were treated with each compound at $6.7,12.5,25,50$ and $100 \mu \mathrm{M}$ in $0.1 \%$ DMSO or $100 \mu \mathrm{M}$ thalidomide, which was used as a control, for $24 \mathrm{~h}$. Cells were washed twice in phosphate-buffered saline (PBS; Thermo Fisher Scientific, Cat\# 10010-023) and lysed in RIPA buffer (Sigma Aldrich, Cat\# R0278-50 ML). Total cell lysates were electrophoresed on NUPAGE 4-12\% Bis (2-hydroxyethyl)- Tris (trishydroxymethyl-aminomethane) gels (Thermo Fisher Scientific, Cat\# NP0321BOX or NP0336BOX) and transferred to polyvinylidene difluoride (PVDF) membranes (Thermo Fisher Scientific, Cat\# IB401001 or IB401002) using an iBlot gel transfer device (Thermo Fisher Scientific). The membranes were blocked in $1 \mathrm{X}$ Tris-buffered saline (TBS; Quality Biological, Cat\# 351-086-131, Gaitherburg, MD) with 0.1\% Tween-20 (Sigma-Aldrich, Cat\# P1379-500 ML) and 5\% blotting grade non-fat dry milk (Bio-Rad, Cat\# 1706404XTU, Hercules, CA) for $1 \mathrm{~h}$ and incubated with anti-acetyl-histone $\mathrm{H} 4$ (1:1000; Cell Signaling Technology,Cat\# 2591 S) antibody at $4{ }^{\circ} \mathrm{C}$ overnight. After washing three times, blots were incubated with 
horseradish peroxidase-conjugated anti-rabbit antibody (GE Healthcare Life Sciences, Cat\# NA934-1 ML, Pittsburgh, PA) and developed using a SuperSignal West Pico Chemiluminescent detection system (Thermo Fisher Scientific, Cat\# 34080). Anti- $\beta$ actin antibody (Santa Cruz Biotechnology, Cat\# sc-47778, Dallas, TX) was used as an internal control.

5.3.6.2. $\gamma$-globin expression in K562 cells. K562 cells were treated with each compound at a final DMSO concentration of $0.1 \%$. Compounds 8(a-b) were dissolved in dimethyl sulfoxide (DMSO; SigmaAldrich, Cat\# D2650-100 ML) to prepare a stock concentration of $100 \mathrm{mM}$. Cells were cultured at $37^{\circ} \mathrm{C}$ in a $5 \% \mathrm{CO}_{2}$ humidified atmosphere. K562 cells $\left(2 \times 10^{5}\right.$ cells $\left./ \mathrm{mL}\right)$ were treated with each compound at $6.7,12.5,25,50$ and $100 \mu \mathrm{M}$ including $0.1 \%$ DMSO or $100 \mu \mathrm{M}$ hydroxyurea, which was used as a control, for $30 \mathrm{~min}$. Cells were washed twice in phosphate-buffered saline (PBS; Thermo Fisher Scientific, Cat\# 10010-023) and lysed in RIPA buffer (Sigma Aldrich, Cat\# R0278-50 ML). Total cell lysates were electrophoresed on NUPAGE 4-12\% Bis (2-hydroxyethyl)-Tris (tris-hydroxymethylaminomethane) gels (Thermo Fisher Scientific, Cat\# NP0321BOX or NP0336BOX) and transferred to polyvinylidene difluoride (PVDF) membranes (Thermo Fisher Scientific, Cat\# IB401001 or IB401002) using an iBlot gel transfer device (Thermo Fisher Scientific). The membranes were blocked in 1X Tris-buffered saline (TBS; Quality Biological, Cat\# 351-086-131, Gaitherburg, MD) with 0.1\% Tween20 (Sigma-Aldrich, Cat\# P1379-500 ML) and 5\% blotting grade non-fat dry milk (Bio-Rad, Cat\# 1706404XTU, Hercules, CA) for $1 \mathrm{~h}$ and incubated with anti-hemoglobin $\gamma$ (1:500; Santa Cruz Biotechnology, Cat\# sc-21756, Dallas, TX) After washing three times, blots were incubated with horseradish peroxidaseconjugated anti-rabbit antibody (GE Healthcare Life Sciences, Cat\# NA934-1 ML, Pittsburgh, PA) or anti-mouse antibody (GE Healthcare Life Sciences, Cat\# NA931-1 ML) and developed using a SuperSignal West Pico Chemiluminescent detection system (Thermo Fisher Scientific, Cat\# 34080). Anti- $\beta$-actin antibody (Santa Cruz Biotechnology, Cat\# sc-47778) was used as an internal control.

5.3.6.3. Phosphorylation of p38 MAPK protein in $K 562$ cells. The effect on the phosphorylation of p38 MAPK protein levels in K562 cells was evaluated by Western blot analysis. Compounds 8(ab) were dissolved in dimethyl sulfoxide (DMSO; Sigma-Aldrich, Cat\# D2650-100 ML) to prepare a stock concentration of $100 \mathrm{mM}$. Cells were cultured at $37^{\circ} \mathrm{C}$ in a $5 \% \mathrm{CO}_{2}$ humidified atmosphere. K562 cells $\left(2 \times 10^{5}\right.$ cells $\left./ \mathrm{mL}\right)$ were treated with each compound at $6.7,12.5,25,50$ and $100 \mu \mathrm{M}$ in $0.1 \%$ DMSO or anisomycin $10 \mu \mathrm{g} \mathrm{mL}^{-1}$ (positive control). Cells were washed twice in phosphate-buffered saline (PBS; Thermo Fisher Scientific, Cat\# 10010-023) and lysed in RIPA buffer (Sigma Aldrich, Cat\# R0278-50 ML). Total cell lysates were electrophoresed on NUPAGE 4-12\% Bis (2-hydroxyethyl)-Tris (tris-hydroxymethyl-aminomethane) gels (Thermo Fisher Scientific, Cat\# NP0321BOX or NP0336BOX) and transferred to polyvinylidene difluoride (PVDF) membranes (Thermo Fisher Scientific, Cat\# IB401001 or IB401002) using an iBlot gel transfer device (Thermo Fisher Scientific). The membranes were blocked in $1 \mathrm{X}$ Tris-buffered saline (TBS; Quality Biological, Cat\# 351-086-131) with 0.1\% Tween-20 (Sigma-Aldrich, Cat\# P1379-500 ML) and 5\% blotting grade non-fat dry milk (Bio-Rad, Cat\# 1706404XTU) for $1 \mathrm{~h}$ and incubated with antibody anti-phospho-p38 (1:1000; Cell Signaling Technology, Cat\# 4511 S, Danvers, MA) or anti-total-p38 (1:1000; Cell Signaling Technology, Cat\# 9212 S) antibodies at $4{ }^{\circ} \mathrm{C}$ overnight. After washing three times, blots were incubated with horseradish peroxidase-conjugated anti-mouse antibody (GE Healthcare Life Sciences, Cat\# NA931-1 ML) and developed using a SuperSignal West Pico Chemiluminescent detection system
(Thermo Fisher Scientific, Cat\# 34080). Anti- $\beta$-actin antibody (Santa Cruz Biotechnology, Cat\# sc-47778) was used as an internal control.

5.3.6.4. Histone $\mathrm{H} 3$ and $\mathrm{H} 4$ acetylation in $\mathrm{K} 562$ cells. K562 cells $\left(2 \times 10^{5}\right.$ cells $\left./ \mathrm{mL}\right)$ were treated with each compound (8a-b) at 6.7, $12.5,25,50$ and $100 \mu \mathrm{M}$ including $0.1 \%$ DMSO or $5 \mathrm{mM}$ sodium butyrate (EMD Millipore, Cat\#19-137, Billerica, MA) $100 \mu \mathrm{M}$ thalidomide used as a control for $24 \mathrm{~h}$. Cells were washed twice in phosphate-buffered saline (PBS; Thermo Fisher Scientific, Cat\# 10010-023) and lysed in RIPA buffer (Sigma Aldrich, Cat\# R0278$50 \mathrm{ML}$ ). Total cell lysates were electrophoresed on NUPAGE $4-12 \%$ Bis (2-hydroxyethyl)-Tris (tris-hydroxymethyl-aminomethane) gels (Thermo Fisher Scientific, Cat\# NP0321BOX or NP0336BOX) and transferred to polyvinylidene difluoride (PVDF) membranes (Thermo Fisher Scientific, Cat\# IB401001 or IB401002) using an iBlot gel transfer device (Thermo Fisher Scientific). The membranes were blocked in 1X Tris-buffered saline (TBS; Quality Biological, Cat\# 351-086-131) with 0.1\% Tween-20 (Sigma-Aldrich, Cat\# P1379-500 ML) with 5\% blotting grade non-fat dry milk (Bio-Rad, Cat\# 1706404XTU) for $1 \mathrm{~h}$ and incubated with anti-acetyl-histone H3 or H4 (1:1000; Cell Signaling Technology, Cat\# 2591 S) antibody at $4{ }^{\circ} \mathrm{C}$ overnight. After washing three times, blots were incubated with horseradish peroxidase-conjugated anti-rabbit antibody (GE Healthcare Life Sciences, Cat\# NA934-1 ML, Pittsburgh, PA) and developed using a SuperSignal West Pico Chemiluminescent detection system (Thermo Fisher Scientific, Cat\# 34080). Anti- $\beta$-actin antibody (Santa Cruz Biotechnology, Cat\# sc47778) was used as an internal control.

\subsubsection{Cytotoxicity test}

XTT assay: Chinese hamster ovary cells (CHO-K1) were grown in 1:1 Ham-F10+D-MEM (Sigma ${ }^{\circledR}$, St. Louis, MO) culture medium supplemented with $10 \%$ (v/v) fetal bovine serum (FBS) (fetal bovine serum - Cultilab, Campinas, Brazil) and antibiotic antimycotic solution (A5955 Sigma ${ }^{\circledR}$, St. Louis, MO) at $37^{\circ} \mathrm{C}$ in a $5 \% \mathrm{CO}_{2}$ atmosphere. Cells were used between the third and eighth passages. For cytotoxicity, genotoxicity and mutagenicity tests, compound $\mathbf{8 b}$ was diluted in $0.5 \%$ DMSO and three concentrations $(100,50$, $25 \mu \mathrm{M})$ were used. As reference, each assay was performed on duplicates within three independent experiments. To perform these experiments CHO-K1 cells were used and the Cell Proliferation Kit II (Roche Applied Science). This test is based on the cleavage of tetrazolium salt (sodium 3'-[1-(phenylaminocarbonyl)-3,4tetrazolium]-bis(4-methoxy-6-nitro) benzene sulfonic acid hydrate) to form an orange formazan dye. Cells were seeded $\left(2 \times 10^{4}\right)$ in 24-well plates in a volume of $1 \mathrm{~mL}$ of HAM-F10: D-MEM medium (1: 1 ) supplemented with $10 \% \mathrm{FBS}$, and incubated at $37^{\circ} \mathrm{C}$ in a $5 \%$ $\mathrm{CO}_{2} 24 \mathrm{~h}$. On the following day, the treatments were carried out for $24 \mathrm{~h}$ with the diluted material in four concentrations $(100,50$, $25 \mu \mathrm{M}$ ). Each well was supplemented with $10 \%$ FBS. Negative controls (NC) were wells with cells and culture medium supplemented with $10 \%$ FBS in the absence of any material (untreated controls). Positive controls (PC) were wells containing CHO-K1 cells treated with doxorubicin $\left(3 \mu \mathrm{g} \mathrm{mL}^{-1}\right)$ for $24 \mathrm{~h}$. After treatment, the cultures were washed with PBS solution and fresh medium was added. In the next day, the cultures were washed with PBS solution and immediately $500 \mu \mathrm{L}$ of DMEM without phenol red were added, followed by the addition of $60 \mu \mathrm{L}$ of the XTT/electron solution (50:1) (Cell Proliferation Kit II - Roche Applied Science). After $3 \mathrm{~h}$ reaction, the supernatant was transferred to a 96-well culture plate, and the absorbance was measured by a Microplate Reader (VersaMax, Molecular Devices, Sunnyvale,CA) at 492 and $690 \mathrm{~nm}$. The absorbance is directly proportional to the number of metabolically active cells (viable cells) in each treatment after $24 \mathrm{~h}$ of exposure. 
Cell viability was calculated from the absorbance and expressed as percentage of viable cells.

\subsubsection{Genotoxicity and mutagenicity assays}

Comet assay: The alkaline version of the comet assay was used according to Singh et al. (1988) [66]. CHO-K1 cells were seeded $\left(5 \times 10^{4}\right.$ cells) and after $24 \mathrm{~h}$ they were exposed to the diluted material in four concentrations $(100,50,25 \mu \mathrm{M})$ for $24 \mathrm{~h}$ in 24 -well plates. Each well was supplemented with $10 \%$ FBS. Negative control (NC) was wells with culture medium supplemented with $10 \%$ FBS in the absence of any material. Positive controls (PC) were cells treated with hydrogen peroxide $\left(80 \mu \mathrm{mol} \mathrm{L}^{-1}\right.$ for $\left.10 \mathrm{~min}\right)$. After exposure, the cultures were washed with PBS solution, trypsin was used, and $500 \mu \mathrm{L}$ of the cell suspension were obtained, kept on ice and protected from light. After centrifugation, the cell pellet was homogenized with $0.5 \%$ low melting point agarose in sufficient volume to $200 \mu \mathrm{L}$. Such material was equally divided and applied on 2 pregelatinized histological slides (Knittel, Germany) with 1.5\% normal melting point agarose (Gibco). They were then covered with coverslips and left in the refrigerator for 10 min when, after careful removal of the cover slip, the slides were immersed in a lysis solution (1\% Triton X-100, 10\% DMSO, $2.5 \mathrm{mmol} \mathrm{L}^{-1} \mathrm{NaCl}$, $100 \mathrm{mmol} \mathrm{L}^{-1} \mathrm{Na}_{2}$ EDTA, $100 \mathrm{mmol} \mathrm{L}^{-1}$ Tris, $\mathrm{pH} \mathrm{10}$ ) for $24 \mathrm{~h}$ protected from light in the refrigerator. Subsequently, the slides were immersed in alkaline electrophoresis $\left(1 \mathrm{mmol} \mathrm{L}^{-1} \mathrm{Na}_{2}\right.$ EDTA, $300 \mathrm{mmol} \mathrm{L}^{-1} \mathrm{NaOH}, \mathrm{pH}>13$ ) for 20 min for DNA denaturation. Then run in electrophoresis at $43 \mathrm{~V}$ and $308 \mathrm{~mA}$ for $25 \mathrm{~min}$. At the end, the slides were immersed in a neutralization buffer $\left(0.4 \mathrm{~mol} \mathrm{~L}^{-1}\right.$ Tris $\left.-\mathrm{HCl}, \mathrm{pH} 7.5\right)$ for $15 \mathrm{~min}$, protected from light in a refrigerator. After drying the slides at room temperature, they were fixed in absolute ethanol for $3 \mathrm{~min}$.

The slides were stained with ethidium bromide $(0.02 \mathrm{mg} / \mathrm{mL})$ and photographed under a fluorescence microscope (ZEISS ${ }^{\circledR}$, Jena, Thuringia, DEU) equipped with an excitation filter of $515-560 \mathrm{~nm}$, a barrier filter of $590 \mathrm{~nm}$ and a $40 \times$ objective. The DNA damage was evaluated by an image analysis system (TriTek CometScore ${ }^{\circledR} 1.5$, 2006, Sumerduck, VA, USA), and the percentage of tail DNA and Tail Moment were obtained for each treatment, with 100 nucleoids analyzed for each treatment.

\subsubsection{Cytokinesis-blocked micronucleus assay (CBMN)}

CBMN assay was carried out to evaluate mutagenicity induced by compound $\mathbf{8 b}$. [43] CHO-K1 cells $\left(37 \times 10^{4}\right.$ cells) were seeded in $25 \mathrm{~cm}^{2}$ culture flasks at $37^{\circ} \mathrm{C}, 5 \% \mathrm{CO}_{2}$. After $24 \mathrm{~h}$ of seeding, cells were exposed for $24 \mathrm{~h}$ to the diluted material in three concentrations $(100,50$ and $25 \mu \mathrm{M})$. Each culture flask was supplemented with $10 \%$ FBS. Negative control (NC) was culture flasks with culture medium supplemented with $10 \%$ FBS in the absence of any material (untreated controls). Positive controls were treated with doxorubicin $\left(0.3 \mu \mathrm{g} \mathrm{mL}^{-1}\right)$ for $4 \mathrm{~h}$. Cytochalasin-B (CytB) was added to the $\mathrm{CHO}-\mathrm{K} 1$ cultures at a final concentration of $5 \mu \mathrm{g} \mathrm{mL}^{-1}$ and left for 20 h. After treatments, the cultures were washed with PBS solution, trypsinized and centrifuged for $5 \mathrm{~min}$ at $406 \times \mathrm{g}$. The pellet was then resuspended in cold hypotonic solution $(0.3 \% \mathrm{KCl}, \mathrm{w} / \mathrm{v})$ for $3 \mathrm{~min}$. Cells were fixed twice with methanol:glacial acetic acid (3:1, $\mathrm{v} / \mathrm{v}$ ), four drops of formaldehyde, and then homogenized carefully. The cell suspensions were dripped on a slide with a film of distilled water at $4{ }^{\circ} \mathrm{C}$. The slides were stained with $5 \%$ Giemsa solution diluted in phosphate buffer $\left(\mathrm{Na}_{2} \mathrm{HPO}_{4} 0.06 \mathrm{~mol} \mathrm{~L}^{-1}, \mathrm{KH}_{2} \mathrm{PO}^{4}\right.$ $0.06 \mathrm{~mol} \mathrm{~L}^{-1}-\mathrm{pH} 6.8$ ) for $7 \mathrm{~min}$, washed with distilled water, air dried and examined by light microscopy ( $400 \times$ magnification $)$.

Five hundred (500) of viable cells were scored to determine the frequency of cells with 1, 2, 3 or 4 nuclei. The nuclear division index (NDI) was calculated using the formula: $[\mathrm{NDI}=\mathrm{M} 1+2(\mathrm{M} 2)+3(\mathrm{M} 3)+4(\mathrm{M} 4) / \mathrm{N}]$, where $\mathrm{M} 1-\mathrm{M} 4$ represents the number of cells with $1-4$ nuclei, respectively, and $\mathrm{N}$ is the total number of viable cells scored [43]. The frequency of binucleated cells with micronuclei (MNBCF) and the total frequency of micronuclei (MF) were scored in 1000 binucleated cell for each treatment. At least 3 experiments were conducted for each analyzed parameter. The results were expressed as mean and standard error (SE). The Shapiro-Wilk test was used to assess the normality of the data and Levene's test for homogeneity. For XTT and Comet assay one-way ANOVA test followed by Tukey's test were applied to the data. In addition, the data from treated groups were compared with the negative control (Dunnett's test). For CBMN assay, the non-parametric Kruskal-Wallis test was applied, followed by Dunn's test. Graphpad Prism 6.0 was used to perform the statistic tests. Differences were considered statistically significant when $\mathrm{p}<0.05$.

\section{Acknowledgments}

This study was supported by Fundação de Amparo à Pesquisa do Estado de São Paulo (FAPESP Ref. Process: 2010/12495-6, 2011/ 15204-5, 2013/04244-1, 2014/06755-6, 2014/00984-3, 2015/ 19531-1 and 2016/09502-7), Programa de Apoio ao Desenvolvimento Científico da Faculdade de Ciências Farmacêuticas da UNESP - PADC and Conselho Nacional de Desenvolvimento Científico e Tecnológico (CNPq Ref. Process: 479468/2013-3 and 310026/20113). The authors are thankful to Ms. Marisa Copolesi for the support in cytokine quantification and Prof. Alberto Gasco from Università degli Studi di Torino, Turin, Italy.

\section{Appendix A. Supplementary data}

Supplementary data related to this article can be found at https://doi.org/10.1016/j.ejmech.2018.05.008.

\section{References}

[1] D.J. Weatherall, W. Dc, J. Weatherall, The Inherited Diseases of Hemoglobin Are an Emerging Global Health burden 115, 2010, pp. 4331-4336.

[2] D.C. Rees, T.N. Williams, M.T. Gladwin, Sickle-cell disease, Lancet 376 (2010) $2018-2031$.

[3] M.T. Gladwin, T. Kanias, D.B. Kim-Shapiro, Hemolysis and cell-free hemoglobin drive an intrinsic mechanism for human disease, J. Clin. Invest. 122 (2012) 1205-1208.

[4] G.J. Kato, V. McGowan, R.F. Machado, J.A. Little, J. Taylor VI, C.R. Morris, J.S. Nichols, X. Wang, M. Poljakovic, S.M. Morris Jr., M.T. Gladwin, Lactate dehydrogenase as a biomarker of hemolysis associated nitric oxide resistance, priapism, leg ulceration, pulmonary hypertrnsion and death in patients with sickle cell disease, Blood 107 (2006) 2279-2285.

[5] R.P. Rother, L. Bell, P. Hillmen, Of Intravascular Hemolysis a Novel Mechanism of Human Disease 293, 2005, pp. 1653-1662.

[6] D. Manwani, P.S. Frenette, Vaso-Occlusion in sickle cell disease: pathophysiology and novel targeted therapies, Blood 122 (2013) 3892-3898.

[7] T.M. Sakamoto, C. Lanaro, M.C. Ozelo, V.T. Garrido, S.T. Olalla-Saad, N. Conran, F.F. Costa, Increased adhesive and inflammatory properties in blood outgrowth endothelial cells from sickle cell anemia patients, Microvasc. Res. 90 (2013) 173-179.

[8] V.N. Hanft, S.R. Fruchtman, C.V. Pickens, W.F. Rosse, T.A. Howard, R.E. Ware, Acquired DNA mutations associated with in vivo hydroxyurea exposure, Blood 95 (2000) 3589-3593.

[9] P.T. McGann, R.E. Ware, Hydroxyurea for sickle cell anemia: what have we learned and what questions still remain? Curr. Opin. Hematol. 18 (2011) $158-165$.

[10] J.L. Dos Santos, C. Lanaro, R.C. Chelucci, S. Gambero, P.L. Bosquesi, J.S. Reis L.M. Lima, H. Cerecetto, M. Gonzalez, F.F. Costa, M.C. Chung, Design, synthesis, and pharmacological evaluation of novel hybrid compounds to treat sickle cell disease symptoms. part II: furoxan derivatives, J. Med. Chem. 55 (2012) $7583-7592$

[11] T. Ferreira de Melo, M. Chin, J. dos Santos, What are the most promising emerging therapies for sickle cell disease? Future Med. Chem. 6 (2014) 979-982.

[12] J.L. dos Santos, C. Lanaro, C.M. Chin, Advances in sickle cell disease Treatment from drug discovery until the patient monitoring, Cardiovasc. Hematol. Agents Med. Chem. 9 (2011) 113-127.

[13] S.P. Perrine, B.S. Pace, D.V. Faller, Targeted fetal hemoglobin induction for 
treatment of beta hemoglobinopathies, Hematol. Oncol. Clin. N. Am. 28 (2014) $233-248$.

[14] V.G. Sankaran, S.H. Orkin, The switch from fetal to adult hemoglobin, Cold Spring Harb. Perspect. Med. 3 (2013).

[15] G.D. Ginder, Epigenetic regulation of fetal globin gene expression in adult erythroid cells, Transl. Res. 165 (2015) 115-125.

[16] W. Aerbajinai, J. Zhu, Z. Gao, K. Chin, G.P. Rodgers, Thalidomide induces gamma-globin gene expression through increased reactive oxygen speciesmediated p38 MAPK signaling and histone H4 acetylation in adult erythropoiesis, Blood 110 (2007) 2864-2871.

[17] C.-H. Hsiao, W. Li, T.-F. Lou, B.S. Baliga, B.S. Pace, Fetal hemoglobin induction by histone deacetylase inhibitors involves generation of reactive oxygen species, Exp. Hematol. 34 (2006) 264-273.

[18] L.A. Moutouh-De Parseval, D. Verhelle, E. Glezer, K. Jensen-Pergakes, G.D. Ferguson, L.G. Corral, C.L. Morris, G. Muller, H. Brady, K. Chan, Pomalidomide and lenalidomide regulate erythropoiesis and fetal hemoglobin production in human CD34+ cells, J. Clin. Invest. 118 (2008) 248-258.

[19] B.M. Dulmovits, A.O. Appiah-Kubi, J. Papoin, J. Hale, M. He, Y. Al-Abed, S. Didier, M. Gould, S. Husain-Krautter, S. a Singh, K.W.H. Chan, A. Vlachos, S.L. Allen, N. Taylor, P. Marambaud, X. An, P.G. Gallagher, N. Mohandas, J.M. Lipton, J.M. Liu, L. Blanc, Pomalidomide reverses $\gamma$-globin silencing through the transcriptional reprogramming of adult hematopoietic progenitors, Blood 127 (2015) 1481-1492.

[20] G. Sorba, C. Medana, R. Fruttero, C. Cena, a. Di Stilo, U. Galli, a. Gasco, Water soluble furoxan derivatives as NO prodrugs, J. Med. Chem. 40 (1997) 463-469.

[21] P.G. Wang, M. Xian, X. Tang, X. Wu, Z. Wen, T. Cai, A.J. Janczuk, Nitric oxide Donors: chemical activities and biological applications, Chem. Rev. 102 (2002) $1091-1134$.

[22] M.R. Miller, I.L. Megson, Recent developments in nitric oxide donor drugs, Br. J. Pharmacol. 151 (2007) 305-321.

[23] A.M.M, O.V. Larionov, Heterocyclic N-Oxides - an emerging class of therapeutic agents, Curr. Med. Chem. 22 (2015) 2819-2857.

[24] M. Feelisch, K. Schönafingeri, H. Noack, Thiol-mediated generation of nitric oxide accounts for the vasodilator action of furoxans, Biochem. Pharmacol. 44 (1992) 1149-1157.

[25] C. Medana, G. Ermondi, R. Fruttero, A. Di Stilo, C. Ferretti, A. Gasco, Furoxans as nitric oxide donors. 4-Phenyl-3-furoxancarbonitrile: thiol-mediated nitric oxide release and biological evaluation, J. Med. Chem. 37 (1994) 4412-4416.

[26] T. Ikuta, S. Ausenda, M.D. Cappellini, Mechanism for fetal globin gene expression: role of the soluble guanylate cyclase-cGMP-dependent protein kinase pathway, Proc. Natl. Acad. Sci. U. S. A 98 (2001) 1847-1852.

[27] A.L. Rosseto, E.M. Pires, C.A. Melchior, L.P. Bosquesi, R.A. Pavan, S. Marcondes, C.M. Chung, L.J. Santos, Synthesis and preliminary evaluation of N-Oxide derivatives for the prevention of atherothrombotic events, Molbank 20 (2015).

[28] F. Blanco, B. Egan, L. Caboni, J. Elguero, J. O'Brien, T. McCabe, D. Fayne, M.J. Meegan, D.G. Lloyd, Study of e/z isomerization in a series of novel nonligand binding pocket androgen receptor antagonists, J. Chem. Inf. Model. 52 (2012) 2387-2397.

[29] Y.K.C. da Silva, C.V. Augusto, M.L. de C Barbosa, G.M. de A Melo, A.C. de Queiroz, T.de L.M.F. Dias, W.B. Júnior, E.J. Barreiro, L.M. Lima, M.S. AlexandreMoreira, Synthesis and pharmacological evaluation of pyrazine N-acylhydrazone derivatives designed as novel analgesic and anti-inflammatory drug candidates, Bioorg. Med. Chem. 18 (2010) 5007-5015.

[30] D. Tsikas, Analysis of nitrite and nitrate in biological fluids by assays based on the Griess reaction: appraisal of the Griess reaction in the 1-arginine/nitric oxide area of research, J. Chromatogr. B 851 (2007) 51-70.

[31] D. Tsikas, Methods of quantitative analysis of the nitric oxide metabolites nitrite and nitrate in human biological fluids, J. Free Radic. Res. 39 (2005).

[32] P.C. Ford, D.A. Wink, D.M. Stanbury, Autoxidation kinetics of aqueous nitric oxide, FEBS Lett. 326 (1993) 1-3.

[33] G.V.R. Born, M.J. Cross, The aggregation of blood platelets, J. Physiol. 168 (1963) 178-195.

[34] H.O.J. Collier, L.C. Dinneen, C.A. Johnson, C. Schneider, The abdominal constriction response and its suppression by analgesic drugs in the mouse, $\mathrm{Br}$. J. Pharmacol. Chemother 32 (1968) 295-310.

[35] P. Koeffler, D.W. Golde, Human Myeloid leukemia cell lines: a review, Blood 56 (1980) 344-350.

[36] B.B. Lozzlo, C.B. Lozzio, Properties and usefullness of the original K-562 human myelogenous leukemia cell line, Leuk. Res. 3 (1979) 363-370.

[37] R. Honerjager, I. Unter, D. Voraussetzungen, D. Rechnung, D. Fall, K562- A Human Erythroleukemic cell line, Int. J. Canc. 23 (1979) 143-147.

[38] OECD, Test No. 487: in vitro mammalian cell micronucleus test, Guidel. Test. Chem. Sect. Heal. Eff. (2014) 1-26.

[39] A.Ö. Yalkinoglu, J.R.R. Schlehofer, H. Zur Hausen, Inhibition of N-methyl-N" nitro-n-nitrosoguanidine-induced methotrexate and adriamycin resistance in CHO cells by adeno-associated virus type 2, Int. J. Canc. 45 (1990) 1195-1203.

[40] A. Atay, V. Bozok Cetina, E. Cal, B. Kosova, A. Kesercioglu, P. Guneri, Cytotoxicity of hard and soft denture lining materials, Dent. Mater. J. 31 (2012)
1082-1086.

[41] R.R. Tice, E. Agurell, D. Anderson, B. Burlinson, A. Hartmann, H. Kobayashi, Y. Miyamae, E. Rojas, J.-C. Ryu, Y.F. Sasaki, Single cell gel/comet assay: guidelines for in vitro and in vivo genetic toxicology testing, Environ. Mol. Mutagen. 35 (2000) 1098-2280.

[42] P. Møller, The alkaline comet assay: towards validation in biomonitoring of DNA damaging exposures, basic, Clin. Pharmacol. Toxicology 98 (2006) $336-345$.

[43] M. Fenech, The in vitro micronucleus technique, Mutat. Res. Mol. Mech. Mutagen 455 (2000) 81-95.

[44] T. Wong, A. Brandow, W. Lim, R. Lottenberg, Evidence-Based Focused Review CME Article Update on the use of hydroxyurea therapy in sickle cell disease, Bloodjournal 124 (2014) 3850-3858.

[45] C.H. Lowrey, Down the repressors! up the fetal hemoglobin!, Blood 127 (2016) 1383-1384.

[46] M.A. Jalali Far, A. Dehghani Fard, S. Hajizamani, M. Mossahebi-Mohammadi, H. Yaghooti, N. Saki, Thalidomide is more efficient than sodium butyrate in enhancing GATA-1 and EKLF gene expression in erythroid progenitors derived from HSCs with $\beta$-globin gene mutation, Int. J. Hematol. Stem Cell Res. 10 (2016) 37-41.

[47] J.L. dos Santos, C.M. Chin, Recent insights on the medicinal Chemistry of sickle cell disease, Curr. Med. Chem. 18 (2011) 2339-2358.

[48] B.S. Pace, L. Liu, B. Li, L.H. Makala, Cell signaling pathways involved in drugmediated fetal hemoglobin induction: strategies to treat sickle cell disease, Exp. Biol. Med. 240 (2015) 1050-1064.

[49] R. Talaat, W. El-Sayed, H.S. Agwa, A.M. Gamal-Eldeen, S. Moawia, M.A.H. Zahran, Anti-inflammatory effect of thalidomide dithiocarbamate and dithioate analogs, Chem. Biol. Interact. 238 (2015) 74-81.

[50] V.P. Cokic, R.D. Smith, B.B. Beleslin-cokic, J.M. Njoroge, J.L. Miller, M.T. Gladwin, A.N. Schechter, Hydroxyurea induces fetal hemoglobin by the nitric oxide - dependent activation of soluble guanylyl cyclase, J. Clin. Invest. 111 (2003) 231-239.

[51] N. Conran, C. Oresco-Santos, H.C. Acosta, A. Fattori, S.T.O. Saad, F.F. Costa, Increased soluble guanylate cyclase activity in the red blood cells of sickle cell patients, Br. J. Haematol. 124 (2004) 547-554.

[52] S.B. King, A role for nitric oxide in hydroxyurea-mediated fetal hemoglobin induction, J. Clin. Invest. 111 (2003) 171-172.

[53] A. Gasco, R. Fruttero, G. Sorba, A. Di Stilo, R. Calvino, NO donors: focus on furoxan derivatives, Pure Appl. Chem. 76 (2004) 973-981.

[54] M. Ilic, D. Kikelj, J. Ilas, Multitarget antithrombotic drugs, Curr. Top. Med. Chem. 11 (2011) 2834-2848.

[55] C.C. Hoppe, Novel therapies targeting the endothelium in sickle cell disease, Hemoglobin 35 (2011) 530-546.

[56] C. Pászty, C.M. Brion, E. Manci, H.E. Witkowska, M.E. Stevens, N. Mohandas, E.M. Rubin, Transgenic knockout mice with exclusively human sickle hemoglobin and sickle cell disease, Science (80-. ) 278 (1997) 876-878.

[57] X. Du, A new mechanism for nitric oxide- and cGMP-mediated platelet inhibition, Blood 109 (2007) 392-393.

[58] P. del Soldato, R. Sorrentino, A. Pinto, NO-aspirins: a class of new antiinflammatory and antithrombotic agents, Trends Pharmacol. Sci. 20 (2017) 319-323.

[59] B.E. Gee, Biologic complexity in sickle cell disease: implications for developing targeted therapeutics, Sci. World J. 2013 (2013).

[60] R.A. Ribeiro, M.L. Vale, S.H. Ferreira, F.Q. Cunha, Analgesic effect of thalidomide on inflammatory pain, Eur. J. Pharmacol. 391 (2000) 97-103.

[61] C. Lanaro, C.F. Franco-Penteado, D.M. Albuqueque, S.T.O. Saad, N. Conran, F.F. Costa, Altered levels of cytokines and inflammatory mediators in plasma and leukocytes of sickle cell anemia patients and effects of hydroxyurea therapy, J. Leukoc. Biol. 85 (2009) 235-242.

[62] I. Akinsheye, A. Alsultan, N. Solovieff, D. Ngo, C.T. Baldwin, P. Sebastiani, D.H.K. Chui, M.H. Steinberg, Fetal hemoglobin in sickle cell anemia, Blood 118 (2011) 19-27.

[63] M. Loesch, H.Y. Zhi, S.W. Hou, X.M. Qi, R.S. Li, Z. Basir, T. Iftner, A. Cuenda, G. Chen, p38 MAPK cooperates with c-Jun in trans-activating matrix metalloproteinase 9, J. Biol. Chem. 285 (2010) 15149-15158.

[64] J.L. Dos Santos, E.A. Varanda, L.M. Lima, C.M. Chin, Mutagenicity of new lead compounds to treat sickle cell disease symptoms in a Salmonella/microsome assay, Int. J. Mol. Sci. 11 (2010) 779-788.

[65] P.P. Chamberlain, A. Lopez-girona, K. Miller, G. Carmel, B. Pagarigan, B. Chieleon, E. Rychak, L.G. Corral, Y.J. Ren, M. Wang, M. Riley, S.L. Delker, T. Ito, H. Ando, T. Mori, Y. Hirano, H. Handa, T. Hakoshima, T.O. Daniel, B.E. Cathers, Structure of the human Cereblon - DDB1 - lenalidomide complex reveals basis for responsiveness to thalidomide analogs, Nat. Struct. Mol. Biol. (2014) $1-8$.

[66] N.P. Singh, M.T. McCoy, R.R. Tice, E.L. Schneider, A simple technique for quantitation of low levels of DNA damage in individual cells, Exp. Cell Res. 175 (1988) 184-191. 